\title{
SHRIMP ZIRCON AGE CONSTRAINTS FROM THE LARSEMANN HILLS REGION, PRYDZ BAY, FOR A LATE MESOPROTEROZOIC TO EARLY NEOPROTEROZOIC TECTONO-THERMAL EVENT IN EAST ANTARCTICA
}

\author{
YANBIN WANG*†, DUNYI LIU*, SUN-LIN CHUNG**, LAIXI TONG***, \\ and LIUDONG REN*
}

\begin{abstract}
This paper reports a geochronological study of granulite-facies rocks from the Larsemann Hills of Prydz Bay, East Antarctica. SHRIMP zircon ages were obtained for a total of 14 samples that cover various rock types including felsic gneiss, mafic gneiss, paragneiss, enderbite, granitic gneiss and leucogneiss. These age results, combined with zircon geochemical data and cathodoluminescence images, enable us to explore the morphological complexity in zircons that record polytectonic events. Features of multiple age zoning, for example, were observed in zircon separates from three felsic gneiss samples studied, which contain magmatic cores of ca. $1.13 \mathrm{Ga}$ and metamorphic mantles and rims of ca. 1.0 and $0.53 \mathrm{Ga}$, respectively. This suggests a period of magmatism and crust formation in the late Mesoproterozoic and two subsequent phases of high-grade metamorphism during the early Neoproterozoic and early Paleozoic, respectively. Similar phenomena of zircon overgrowth were also observed in other rock types. Although early Paleozoic tectonic activity has been considered as most significant in Antarctic crustal evolution, our study provides the first convincing age evidence for the existence of a Prydz Bay late Mesoproterozoic mobile belt. The ca. 1.0 Ga metamorphic record preserved in diverse rocks from the study area furthermore supports the proposal of a continuous circum East Antarctica late Mesoproterozoic (Grenville-age) orogenic belt. Within this framework, the Prydz Bay orogen is proposed to have been located in the central part of the Rodinia assembly that brought the Eastern Ghats of India together with Antarctica at ca. 1.0 Ga.
\end{abstract}

INTRODUCTION

Granulite-facies rocks in the Larsemann Hills, Prydz Bay (fig. 1), represent an important suite for investigating the development of high-grade metamorphic terrains in East Antarctica. The tectono-thermal event that produced these granulite-facies rocks has long been considered to be of late Mesoproterozoic age (Tingey, 1981, 1982, 1991; Black and others, 1987; Stüwe and others, 1989), based essentially on a Rb-Sr whole-rock isochron age of $1050 \pm 109 \mathrm{Ma}$ (Tingey, 1981), obtained on felsic gneisses in the Rauer Group of Filla Island, Prydz Bay (fig. 1). This event was henceforth termed the 1100 Ma event, and the idea of a so-called "Prydz Bay Grenville-age mobile belt" proposed (see Fitzsimons, 2000, for review). These, combined with the widespread occurrence of ca. 1.1 to $1.0 \mathrm{Ga}$ records over East Antarctica, eventually led to the inference of a "Circum-East Antarctic mobile zone" that may be linked with metamorphic belts of similar age in southern India, part of East Africa, Sri Lanka, and Australia to form the main suture in a Rodinia configuration. (for example, Moores, 1991; Dalziel, 1991; Hoffman, 1991; Powell and others, 1993; Torsvik, 2003). However, more recent studies cast serious doubt on the earlier interpretations by showing time constraints that suggest the region to have experienced Pan-African granulite-facies metamorphism in the early Paleozoic (ca. $500 \mathrm{Ma}$ ) (Zhao and others, 1992, 1995, 1997, 2003; Hensen and Zhou, 1995, 1997; Carson and others, 1996; Fitzsimons and others,

\footnotetext{
*Beijing SHRIMP Center, Institute of Geology, Chinese Academy of Geological Sciences, 26 Baiwanzhuang Road, Beijing, 100037, China

***Department of Geosciences, National Taiwan University, Taipei 10699, Taiwan

***Institute of Earth Sciences, Academia Sinica, Taipei 115, Taiwan

†Corresponding author: wangyanbin@bjshrimp.cn
} 


\section{LOCATION MAP OF THE \\ PRYDZ BAY COAST LINE}

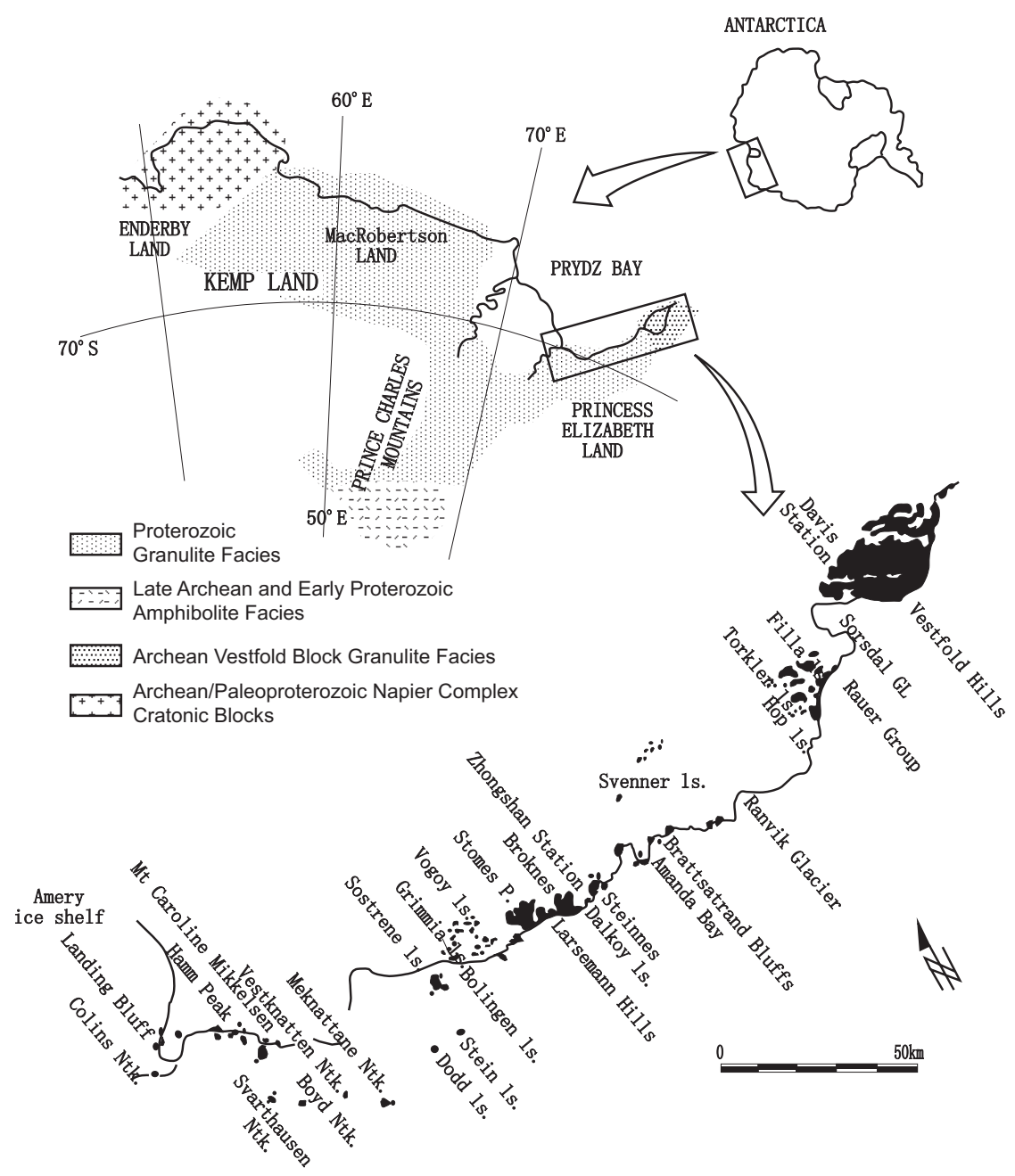

Fig. 1. Location and regional geological setting of the Larsemann Hills, East Antarctica (modified from Stüwe and others, 1989).

1997), and led to the widely accepted view that the Pan-African event played a significant role in the tectonic evolution of the East Antarctic Shield. Given the fact that the paucity of precise age data hinders geologic correlations and understanding of the tectonic evolution, we conducted a detailed zircon U-Pb age study of metamorphic rocks from the Larsemann Hills and adjacent area by using the sensitive highresolution ion microprobe (SHRIMP) method. In this paper, we present and discuss SHRIMP zircon ages from fourteen samples collected from the Larsemann Hills and adjacent areas. These include three samples of felsic gneiss (samples 9926-5, 9921-14 and K217-3), four mafic gneiss samples (samples 93122-15, F129-1, K217-4 and V218-5,), three Grt-Sill-Br-gneiss samples (samples 981227-1, S226-4 and V218-4), and an enderbite (sample 981221-2), two grantic gneiss (samples F127-4 and S204-1), and one leucogneiss (sample 981230-1). 
Our results constrain the ages of protolith formation as well as subsequent metamorphism and allow us to refine the temporal framework of magmatic and metamorphic processes in the region. Along with reporting precise zircon ages supportive of the notion of widespread early Neoproterozoic tectono-thermal event, broader implications for the tectonic evolution of East Antarctica are also discussed in this paper.

REGIONAL GEOLOGY AND PREVIOUS STUDIES

The Larsemann Hills and adjacent areas, from the Vögoy Island, northern Bolingen Islands to the Steinnes Peninsula (figs. 1 and 2), consist of upper amphibole- to granulite-facies metamorphic rocks. These areas are dominated by two major lithological associations, (1) composite mafic to felsic orthogneiss complexes, and (2) metasedimentary sequences comprising metapelite, semipelite, psammite, felsic paragneiss and metaquartzite. The rocks are extensively migmatized and/or intruded by magmatic rocks including granitic gneiss, leucogneiss, enderbite, granite and pegmatite (Fitzsimons and Harley, 1991; Dirks and Hand, 1995; Carson and others, 1995; Fitzsimons and others, 1997).

Peak metamorphism in the region has been estimated at $7 \mathrm{kbar}$ and 800 to $850{ }^{\circ} \mathrm{C}$ (Wang and others, 1994; Carson and others, 1995), with the post-peak evolution characterized by decompression. In some garnet-bearing mafic granulites from Søstrene Island, two-stage decompression phenomena were observed so that two phases of high-grade metamorphism are inferred and the earlier one's P-T condition were estimated to be $\sim 10 \mathrm{kbar}$ and $980{ }^{\circ} \mathrm{C}$ (Thost and others, 1991). Such high P-T conditions were also reported by: (1) Ren and others (1992) for gneiss from the Larsemann Hills $\left(9\right.$ kbar and $850{ }^{\circ} \mathrm{C}$ ), (2) Dirks and Hand (1995) for the possible presence of sillimantite pseudomorphs after kyanite in metapelite from north Bollingen Islands (>10 kbar and $980{ }^{\circ} \mathrm{C}$ ), and (3) Tong and Liu (1997) for mafic granulite from Larsemann Hills (9.5 kbar and $\left.870{ }^{\circ} \mathrm{C}\right)$.

Sheraton and others (1984) reported $\mathrm{Rb}-\mathrm{Sr}$ and Sm-Nd whole-rock isotopic data for various rock samples from the Prydz Bay area which include: (1) Rb-Sr whole-rock isochrons of $1600+800 /-340$ Ma for orthopyroxene gneisses from the Rauer Group,

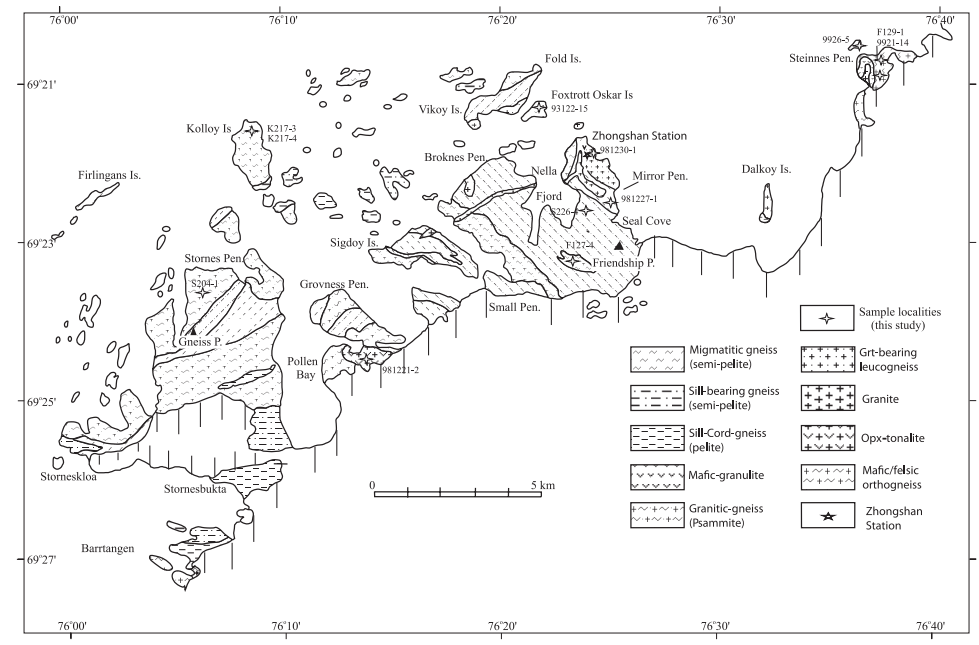

Fig. 2. Simplified geologic map of the Larsemann Hills and sample localities (modified from Stüwe and others, 1989; Carson and others, 1995). 
$1360+330 /-190 \mathrm{Ma}$ for garnet gneisses, $560 \pm 70 \mathrm{Ma}$ for metapelites, and (2) a Sm-Nd whole-rock isochron of $1470 \pm 600$ Ma for six metapelites. More recently, Zhao and others (1995) reported $\mathrm{Nd} \mathrm{T}_{\mathrm{DM}}$ model ages of 2200 to $700 \mathrm{Ma}$ for seven samples of gneisses and granitoids from Larsemann Hills. Carson and others $(1995,1997)$ argued that the mafic-felsic composite orthogneiss from Larsemann Hills and adjacent areas may represent an Archean/Paleoproterozoic basement complex, based on its lithological similarity with mafic-fesic orthogneisses from the southeastern Rauer Group and the Berrneset Peninsula, dated to be of Archean and Paleoproterozoic ages, respectively (Sheraton and others, 1984). Zircon dating from the western and northern Rauer Group (Kinny and others, 1993) identified a 1000 Ma event. Subsequently, the basement complex underwent high P-T metamorphism during a late Mesoproterozoic tectono-thermal event, based on a Rb-Sr isochron age of $1050 \pm 109 \mathrm{Ma}$ reported by Tingey (1981), and thus had been considered as part of the extensive high-grade metamorphic complex of East Antarctica (Tingey, 1982, 1991; Black and others, 1987; Stüwe and others, 1989).

However, numerous early Paleozoic (ca. 550 - $500 \mathrm{Ma}$ ), rather than early Neoproterozoic, ages were obtained for mafic-felsic gneiss and paragneiss from the region (Zhao and others, 1992, 1995; Hensen and Zhou, 1995; Fitzsimons and others, 1997), which led to the suggestion that the granulite-facies metamorphism should have occurred at ca. 0.5 Ga. Early Paleozoic metamorphism in the Prydz Bay region has furthermore been related to continental collision, followed by extensional collapse (Fitzsimons and Harley, 1991; Fitzsimons, 1991, 1996, 2000; Thost and others, 1991). In such a framework, several ca. 1200 to 600 Ma cores of zircon grains in the Progress granite and a paragneiss from the Larsemann Hills (Zhao and others, 1995; Carson and others, 1995), dated by SHRIMP and $\mathrm{Pb}-\mathrm{Pb}$ evaporation methods, respectively, were interpreted as reflecting various degrees of inheritance from their sedimentary source rocks.

The prevailing early Paleozoic record, however, does not preclude the existence of an earlier high-grade metamorphism, although the latter may have been overprinted and/or obscured by the former. "Relicts" of older events observed include: (1) a whole-rock Sm-Nd isochron age of ca. 1.0 Ga for garnet-bearing mafic granulites from the Søstrene Island, Prydz Bay (Hensen and Zhou, 1995); (2) upper Concordia intercept ages of $1106 \pm 11$ and $1174 \pm 450$ Ma for zircons and monazites, respectively, from garnet-biotite-bearing quartzite from the Stornes Peninsula (Zhang and others, 1996); (3) a U-Pb zircon age of $772+71 /-48$ Ma for a mafic granulite from the northern Mirror Peninsula (Tong and others, 1995); (4) two ${ }^{40} \mathrm{Ar}-{ }^{39} \mathrm{Ar}$ plateau ages of $1034 \pm 14$ and $554 \pm 26$ Ma for hornblende in mafic gneiss from Kolloy Island; two ${ }^{40} \mathrm{Ar}^{39}{ }^{39} \mathrm{Ar}$ plateau ages of $1059 \pm 3$ and $555 \pm 16$ Ma for orthopyroxene in mafic gneiss from Stornesbukta; and a ${ }^{40} \mathrm{Ar}^{39}{ }^{39} \mathrm{Ar}$ plateau age of $774 \pm 3$ Ma for plagioclase in a garnet-plagioclase-bearing amphibolite from Kolloy Island (Tong and others, 1998, 2002).

\section{SAMPLES AND ANALYTICAL METHODS}

14 representative samples from the major rock units were selected for zircon U-Pb dating. These include: (1) 3 felsic gneisses, (2) 4 mafic gneisses, (3) 3 metasedmentary rocks, (4) an enderbite, (5) 2 granitic gneisses, and (6) a leucogneiss. Sample localities are shown in figure 2, with sample descriptions being given in the Appendix.

\section{SHRIMP ZIRCON ANALYSES}

Zircons were separated using standard heavy liquid and magnetic techniques. Grains were hand-picked and selected on the basis of optical clarity and lack of internal fractures. Zircon grains were mounted in an epoxy disk together with grains of the Sri Lankan reference zircon SL-13 for U concentration determination (Williams, 1998) 
and the Temora zircon standard (Black and others, 2003) for U-Pb age calibration. Zircon grains were sectioned approximately in half and polished, and images were obtained by optical microscopy and cathodoluminenscence (CL) on a scanning electron microscope. With CL images, it is possible to distinguish the internal structure of zircons, including igneous and metamorphic crystallization textures, resorption surfaces, and overgrowths. Analyses were carried out on the SHRIMP II ion microprobe in the Beijing SHRIMP Center, Institute of Geology, Chinese Academy of Geological Sciences. The analytical methods are given by Williams (1998). Each analysis consisted of seven scans through the mass range, using a spot size of $\sim 20 \mu \mathrm{m}$. For grains with fine-scale internal structure, a smaller spot size of $\sim 10$ to $15 \mu \mathrm{m}$ was used. $\mathrm{U} / \mathrm{Pb}$ ratios were calibrated relative to $417 \mathrm{Ma}$ Temora zircons (Black and others, 2003), with data reduction using the SQUID Excel Macro software by Ludwig (2001). Common $\mathrm{Pb}$ contribution was corrected using the measured ${ }^{204} \mathrm{~Pb}$ and modal common $\mathrm{Pb}$ composition (Stacey and Kramers, 1975). Uncertainties in the measured ratios are given at the one sigma level, whereas weighted mean age uncertainties are reported at two sigma or 95 percent confidence level. Calculated ages are based on weighted mean ${ }^{206} \mathrm{~Pb} /{ }^{238} \mathrm{U}$ and ${ }^{207} \mathrm{~Pb} /{ }^{206} \mathrm{~Pb}$ isotopic ratios for near- concordant zircons (Ireland and Gibson, 1998). ${ }^{206} \mathrm{~Pb} /{ }^{238} \mathrm{U}$ ages are reported for zircons younger than 800 , whereas the ${ }^{207} \mathrm{~Pb} /{ }^{206} \mathrm{~Pb}$ ages are presented for zircons older than $800 \mathrm{Ma}$.

\section{ZIRCON AGES}

The description of field relationships of representative samples are given in the Appendix.

\section{FELSIC GNEISSES}

1.1. Sample 9926-5 (plagioclase-orthopyroxene gneiss, Steinnes Peninsula).- - The sample contains small $(60-120 \mu \mathrm{m})$, yellowish, irregularly shaped, and mostly rounded to stubby zircons with distinct core-rim structures. CL images show that most zircons have complex internal structures (figs. $3 \mathrm{~A}$ and 3B). The cores show magmatic growth zoning with highly variable $\mathrm{U}$ concentrations from 185 to $2,462 \mathrm{ppm}$ and $\mathrm{Th} / \mathrm{U}$ ratios from 0.20 to 1.25 . Some zircons have two generations of overgrowth as manifested by (1) an inner rim that has high $\mathrm{U}$ concentrations of 1,161 to $2,183 \mathrm{ppm}$ and $\mathrm{Th} / \mathrm{U}$ ratios $<0.39$, and $(2)$ an outer rim that has lower $\mathrm{U}$ concentrations $(678-1,012 \mathrm{ppm})$ and $\mathrm{Th} / \mathrm{U}$ ratios $(<0.17)$.

Twenty-three spots on 18 zircons were analyzed (table 1). Eight core analyses are concordant (fig. 4A) and yielded a weighted mean ${ }^{207} \mathrm{~Pb} /{ }^{206} \mathrm{~Pb}$ age of $1119 \pm 13 \mathrm{Ma}$ $(\mathrm{MSWD}=2.4)$. Slightly discordant cores suggest isotopic disturbance. The above age is interpreted to date crystallization of the gneiss protolith. Three analyses of the inner rims (rim 1) are also concordant (fig. 4A) and yielded a weighted mean ${ }^{207} \mathrm{~Pb} /{ }^{206} \mathrm{~Pb}$ age of $997 \pm 13 \mathrm{Ma}(\mathrm{MSWD}=0.80)$. Four spots were measured on the outer rims (rim $2)$. Three spots $(10.1,10.2,10.3)$ are structureless in their CL images and gave variable ${ }^{206} \mathrm{~Pb} /{ }^{238} \mathrm{U}$ ages of $671 \pm 11 \mathrm{Ma}(1 \sigma, \mathrm{U}=905 \mathrm{ppm}, \mathrm{Th} / \mathrm{U}=0.06), 579 \pm 2 \mathrm{Ma}(1 \sigma, \mathrm{U}=$ $921 \mathrm{ppm}, \mathrm{Th} / \mathrm{U}=0.14)$ and $546 \pm 7 \mathrm{Ma}(1 \sigma, \mathrm{U}=1012 \mathrm{ppm}, \mathrm{Th} / \mathrm{U}=0.17)$, respectively, whereas the fourth spot (analysis 4.2 ) gave a ${ }^{206} \mathrm{~Pb} /{ }^{238} \mathrm{U}$ age of $667 \pm 13$ Ma $(1 \sigma, \mathrm{U}=678 \mathrm{ppm}, \mathrm{Th} / \mathrm{U}=0.11)$. Some outer rims (for example, grain 14 , fig. 3A) were too narrow for SHRIMP analysis. On figure 4A there is a large spread from 1140 to ca. $980 \mathrm{Ma}$, and the selected inner rims (rim 1) also spread either side of $1000 \mathrm{Ma}$, suggesting profound disturbance at $530 \mathrm{Ma}$.

In summary, these data indicate a complex history for felsic gneiss sample 9926-5 whose zircons show evidence of magmatism at $1119 \pm 13 \mathrm{Ma}$, suggesting primary crystallization of the gneiss protolith from an igneous melt. The rock was subsequently overprinted during two phases of high-grade metamorphism with zircon growth at 


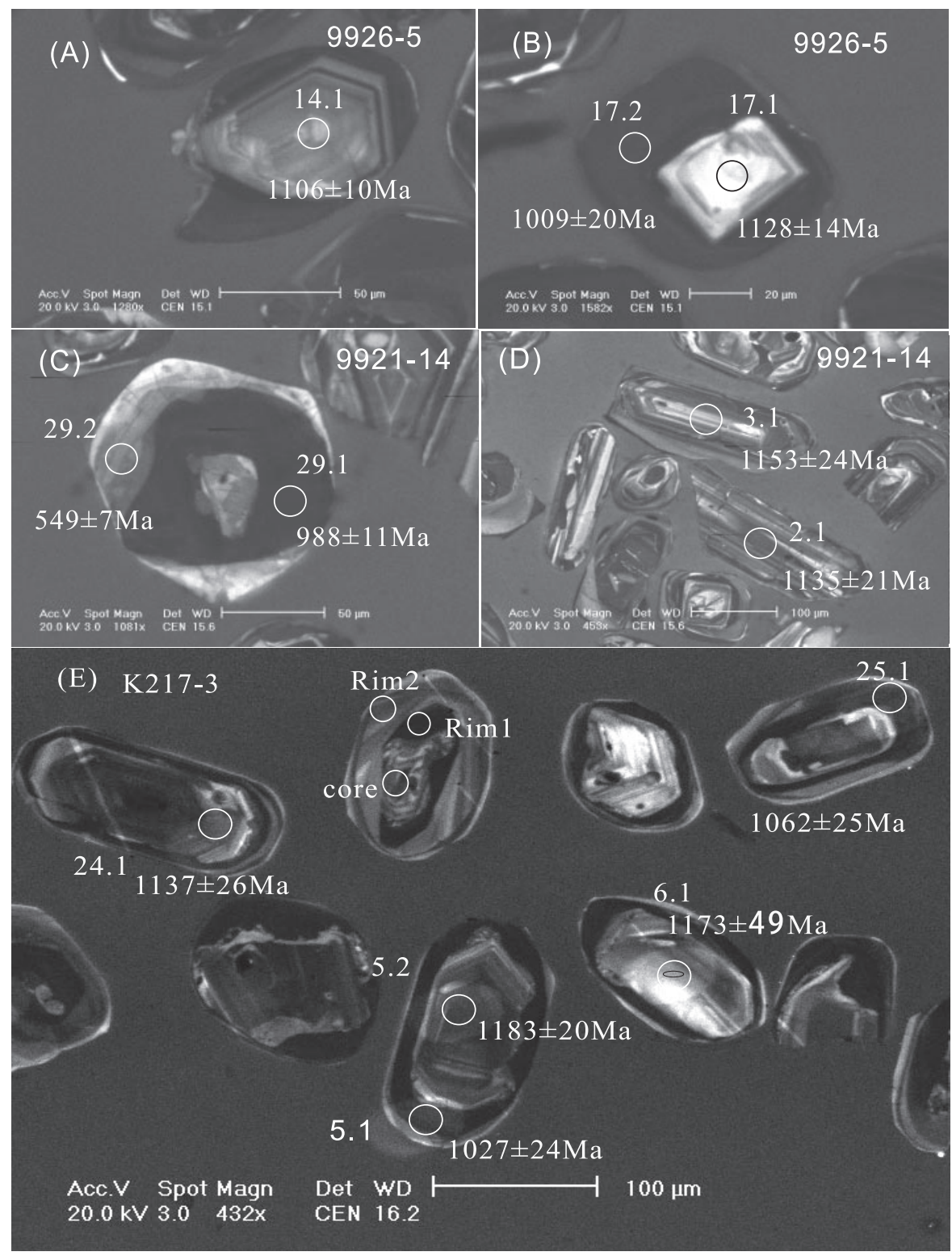

Fig. 3. CL images of dominant zircon morphologies from felsic gneiss samples. Numbered ellipsoids indicate SHRIMP spots. (A) and (B) Images of inherited magmatic cores with a small-volume isometric high-U zircon overgrowth. (C) Grain 29 shows a core and a complex overgrowth yielding riml (ca. $1.0 \mathrm{Ga}$ ) and rim2 $(0.55 \mathrm{Ga})$ ages. (D) Grain 3 shows interior oscillatory growth banding of a euhedral igneous crystal formed at about $1.15 \mathrm{Ga}$, truncated by a curved resorption surface, upon which texturally homogeneous metamorphic overgrowth possibly formed at ca. 1.0 Ga. (E) Cathodoluminescence images of sample K217-3. Highly luminescent zircon cores are of magmatic origin. Cores are overgrown by two generations of zircon rims. The first rim has an age of ca. $1.0 \mathrm{Ga}$ and is thought to reflect Grenville-age metamorphism, the second rim probably reflects $0.5 \mathrm{Ga}$ high-grade reworking of the area.

ca. $1000 \mathrm{Ma}$ and ca. $546 \mathrm{Ma}$. The oldest metamorphic rim at ca. $1000 \mathrm{Ma}$ is probably related to metamorphism associated with the older $\mathrm{D}_{1}$ deformation (Fitzsimons and Harley, 1991), whereas the outer rim dated at ca. 546 Ma is likely to be related to late 


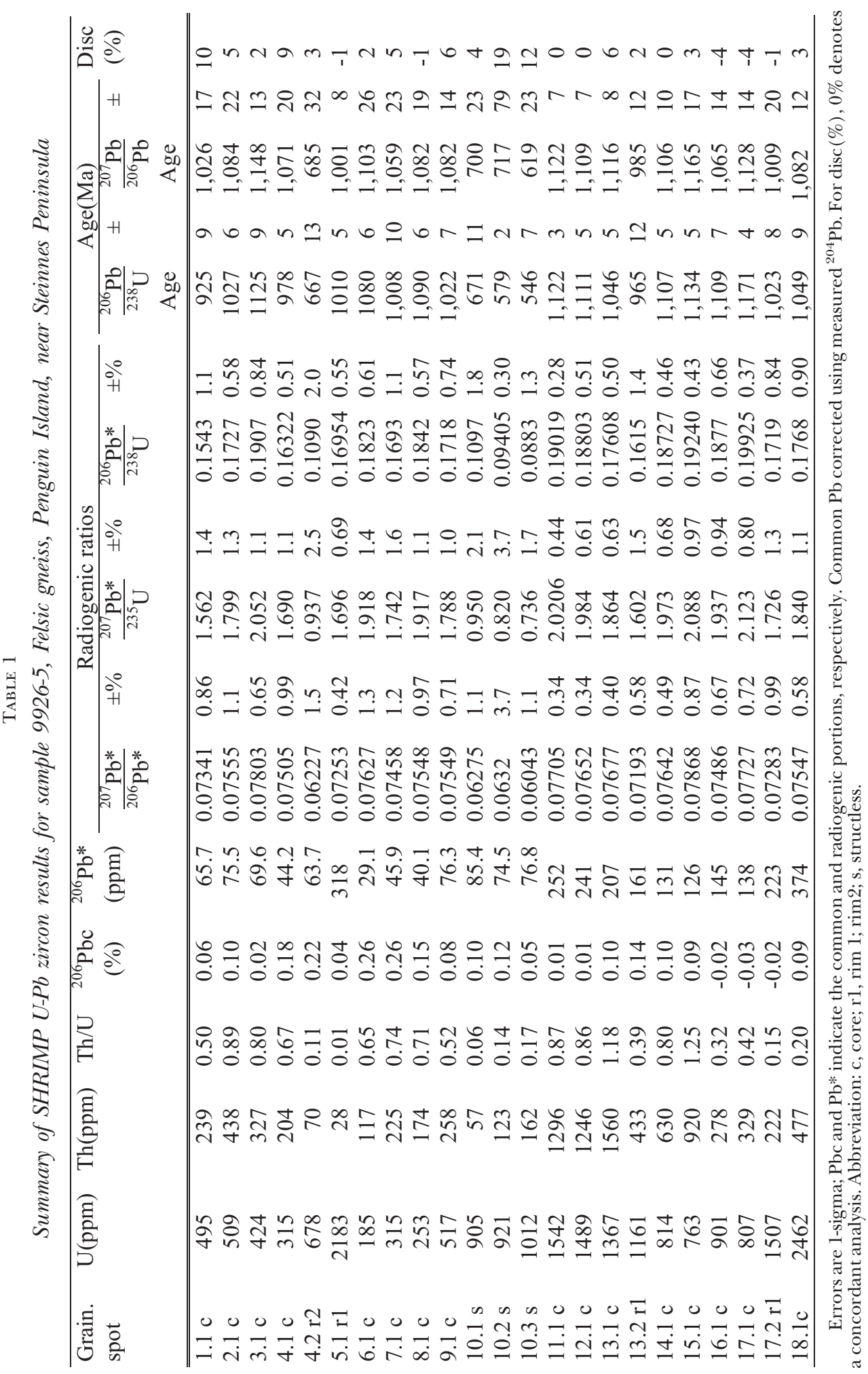


580 Y. Wang and others—Shrimp zircon age constraints from the Larsemann Hills region,
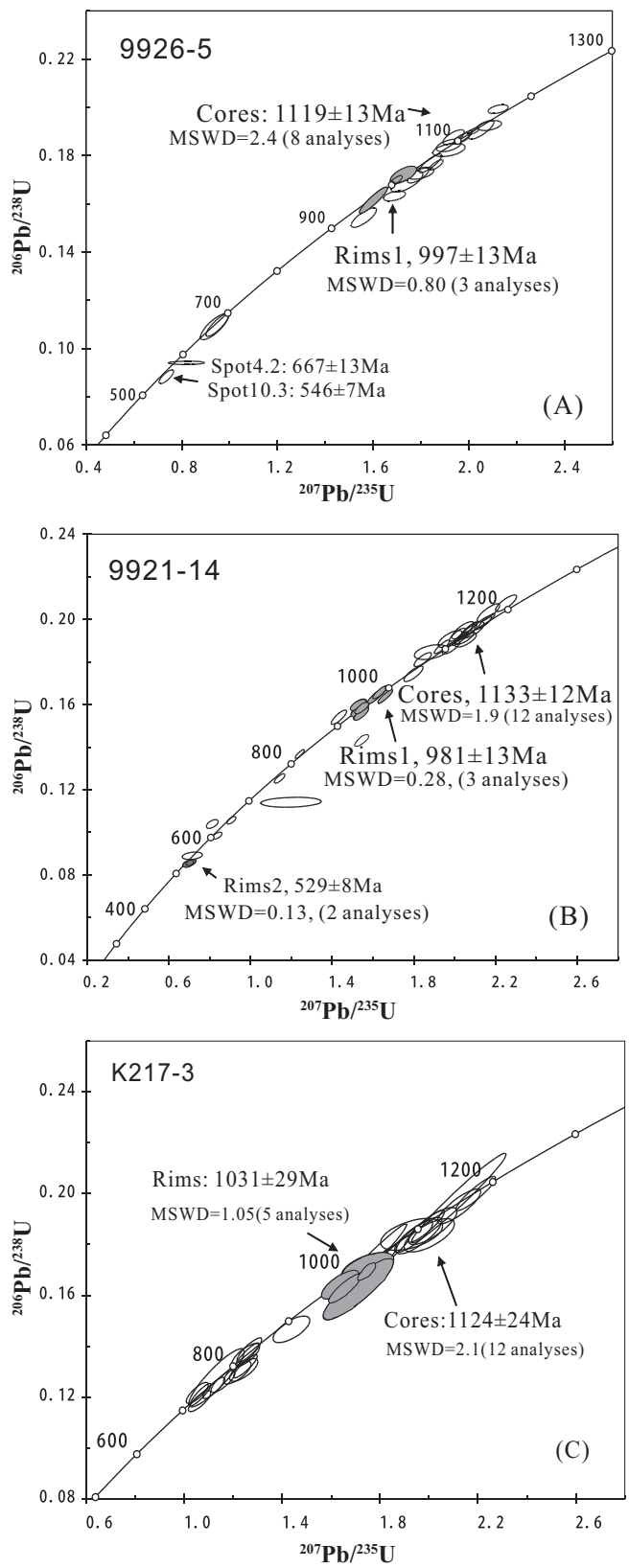

Fig. 4. A-C Concordia diagrams of SHRIMP-dated zircons. (A) Felsic gneiss 9926-5 from small Island north of Steinnes Peninsula; (B) Felsic gneiss 9921-14 from Steinnes Peninsula; (C) Felsic gneiss K217-3 from Kolloy Island. Error ellipses are $1 \sigma$.

deformation (Fitzsimons and Harley, 1991; Dirks and others, 1993; Carson and others, 1995; Dirks and Hand, 1995).

1.2. Sample 9921-14 (quartz-plagioclase gneiss, Steinnes Peninsula)._Zircons from this felsic gneiss are dominated by clear to brownish grains, ranging in size between 60 and 
$250 \mu \mathrm{m}$. The zircons population consist of grains with different morphologies, showing a complete range from prismatic to spherical. Prismatic grains generally have rounded terminations, suggesting zircon dissolution during high-grade metamorphism. Variable degrees of rounding produced spherical grains that occur in addition to multifaceted zircons that grew during granulite-facies metamorphism.

Cathodoluminescence (CL) images exhibit two types of internal patterns. Type 1 occurs in well rounded and multifaceted grains and is characterized by the presence of patchy zonation within inherited cores (see for example fig. 3C), surrounded by wide high-U overgrowth; small and discontinuous rims are common for this type. The grains are not homogeneous but exhibit core-mantle-rim textures with different CL intensities (for example, fig. 3C). Type 2 (prismatic zircon) consists of inherited cores with oscillatory zoning surrounded by thin rims (for example, fig. 3D).

We focus on the $\sim 1133 \mathrm{Ma}, \sim 981 \mathrm{Ma}$ and $\sim 529 \mathrm{Ma}$ age groups (fig. 4B). Zircons of these age groups are distinguished by their CL images (figs. 3C and 3D). Nineteen core areas of magmatic zircons were analyzed in this study (table 2). These all have $\mathrm{Th} / \mathrm{U}$ ratios in the range of 0.3 to 1.0 , similar to those determined for late Mesoproterozoic magmatic zircons from sample 9926-5. Twelve analyses provide a weighted mean ${ }^{207} \mathrm{~Pb} /{ }^{206} \mathrm{~Pb}$ age of $1133 \pm 12 \mathrm{Ma}(\mathrm{MSWD}=1.9)$. Three weakly luminescent mantle areas (rim1) yielded a weighted mean ${ }^{206} \mathrm{~Pb} /{ }^{238} \mathrm{U}$ age of $981 \pm 13 \mathrm{Ma}(\mathrm{MSWD}=0.28)$. We interpret $\sim 1000 \mathrm{Ma}$ as the best estimate for the age of late Mesoproterozoic metamorphism in this sample. We explain the zircon domains as the result of metamorphic recrystallization because of a lack of igneous growth features, low $\mathrm{Th} / \mathrm{U}$ ratios, and general concordance at an age that cannot be produced by simple isotopic disequilibrium between the $\sim 1133 \mathrm{Ma}$ and $\sim 530 \mathrm{Ma}$ events. Therefore, the $\sim 1000 \mathrm{Ma}$ zircon domains in this gneiss, like those in sample 9926-5, may reflect hightemperature metamorphism that was contemporaneous with spatially associated magmatic events. Two analyses of zircon rims yielded early Paleozoic ages with a mean of $529 \pm 8 \mathrm{Ma}(\mathrm{MSWD}=0.13)$, Analysis 1.2 is very discordant, and is not further considered here.

Zircons in this gneiss reveal a multi-stage history beginning with $\sim 1133 \mathrm{Ma}$ magmatism, followed by $\sim 1000$ Ma high-grade metamorphism and $\sim 530$ Ma metamorphism and partial melting. The age distribution and isotopic behavior of the total zircon population resemble that of sample 9926-5 with multiple age components analyzed from discrete domains. We argue that initial $\sim 1133$ Ma magmatism and first metamorphism may reflect the late Mesoproterozoic event at $\sim 1000 \mathrm{Ma}$ whereas the second metamorphism may reflect the early Paleozoic event at $\sim 530 \mathrm{Ma}$.

1.3 Sample K217-3 (orthopyroxene-bearing felsic gneiss, Kolloy Island).-The sample contains round and elongate, clear to honey-yellowish zircons between 100 and 200 $\mu \mathrm{m}$ in length. CL imaging shows cores with magmatic zonation; these cores are surrounded, entirely or in part, by a structureless, weakly luminescent mantle ( $\operatorname{rim} 1)$ which reflects an early period of zircon growth. All grains have an outermost thin overgrowth (rim2), attributed to late resorption (fig. 3E). The magmatic cores have medium U-concentrations (264-772 ppm), whereas the metamorphic rims1 and resorbed areas are high in $\mathrm{U}$. Twenty nine areas have been analyzed, with both magmatic cores and metamorphic mantles (rim1) targeted (fig. 4C and table 3). Twelve core analyses give a weighted mean ${ }^{207} \mathrm{~Pb} /{ }^{206} \mathrm{~Pb}$ age of $1124 \pm 24 \mathrm{Ma}$ $(\mathrm{MSWD}=2.1)$ which is interpreted to date zircon crystallization close to the time of emplacement of the orthogneiss precursor. Five analyses of rim 1 give a weighted mean ${ }^{207} \mathrm{~Pb} /{ }^{206} \mathrm{~Pb}$ age of $1031 \pm 29 \mathrm{Ma}(\mathrm{MSWD}=1.05)$. One analysis from grain 5 with a metamorphic mantle yielded a concordant ${ }^{207} \mathrm{~Pb} /{ }^{206} \mathrm{~Pb}$ age of $1027 \pm 24 \mathrm{Ma}$. This metamorphic age is identical to that in samples $9926-5$ and $9921-14$, within error, and indicates igneous crystallization at ca. $1100 \mathrm{Ma}$, followed by resorption and new 
582 Y. Wang and others—Shrimp zircon age constraints from the Larsemann Hills region,

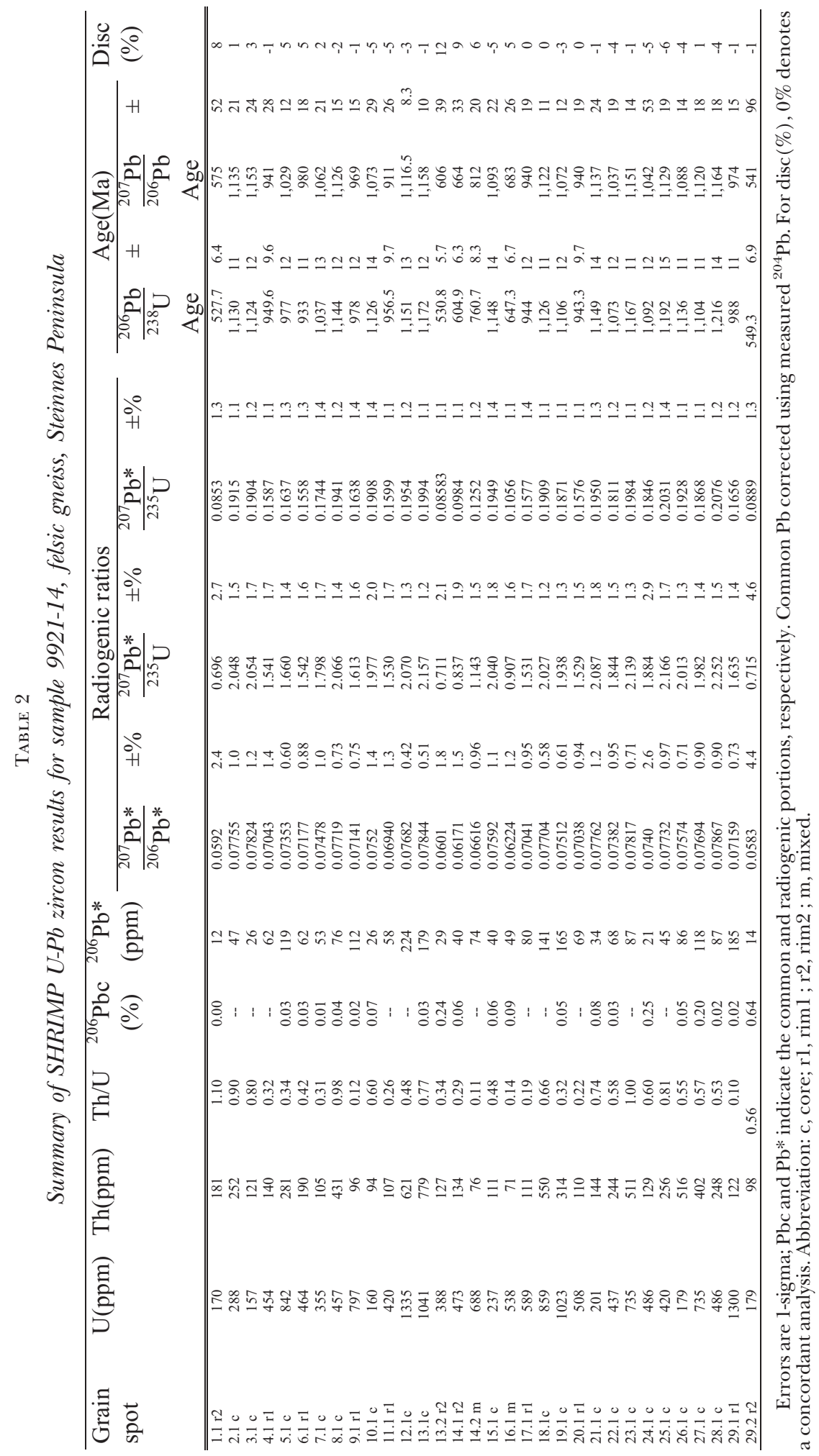




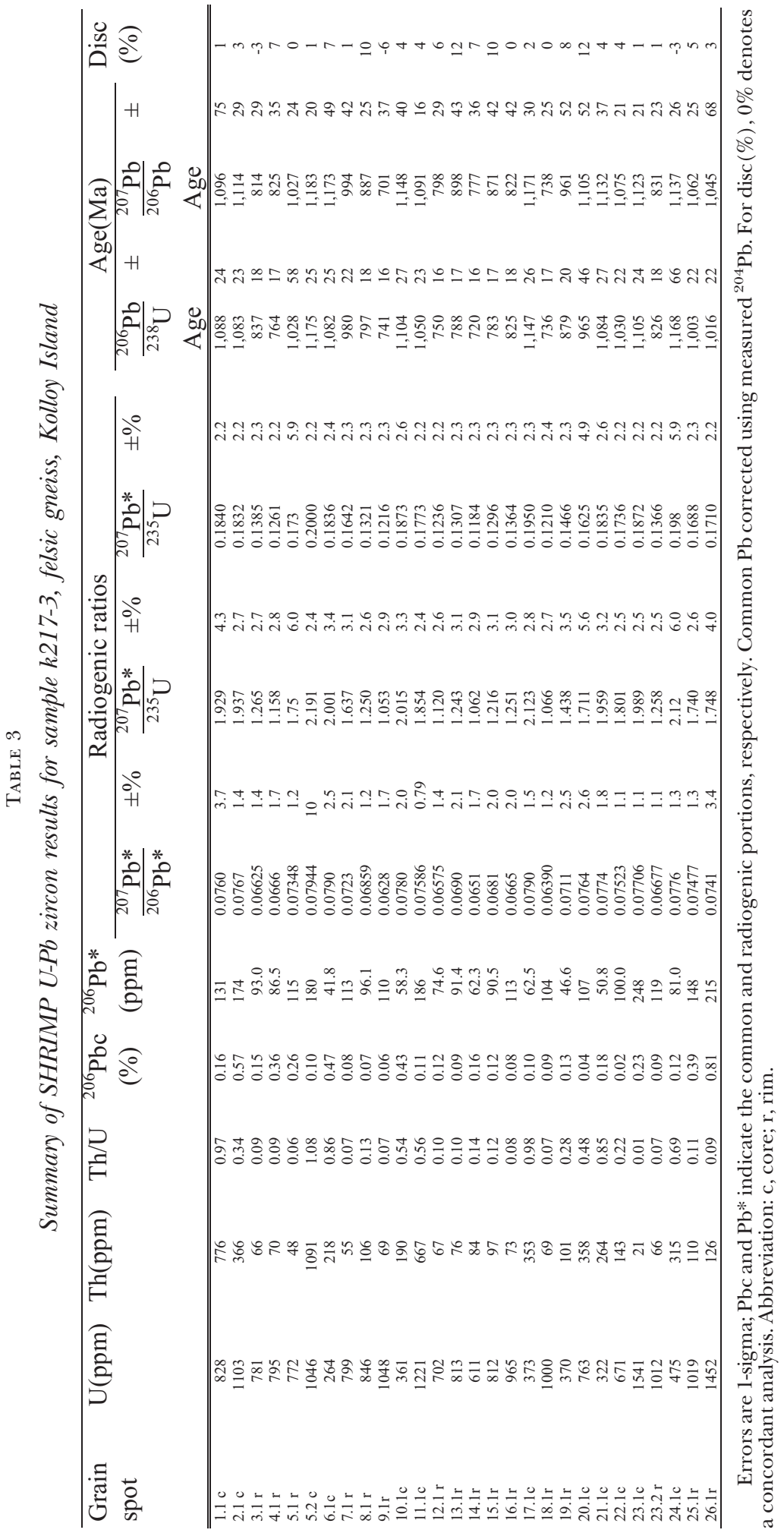


metamorphic growth at ca. $1000 \mathrm{Ma}$. The other mantle (rim1) ages of 736 to $837 \mathrm{Ma}$ probably reflect isotopic mixtures without geological relevance, because the evolution of the felsic gneiss involved polyphase reworking of diverse late Mesoproterozoic crustal precursors during a ca. 1.0 Ga granulite-facies event, and a superimposed granulite-facies episode at ca. $0.53 \mathrm{Ga}$ in high strain zones. CL images show that substantial new zircon growths $(1.0 \mathrm{Ga}$ and $0.53 \mathrm{Ga})$ around pre-existing magmatic zircon core grains occurred twice. Recrystallization in some zircon grains may have been incomplete, leaving a "memory" of the previous isotopic event. Isotopic analysis of such an area will yield an age older than the event inducing late recrystallization and younger than the early recrystallized zircon (Hoskin and Black, 2000). The data points plot along the concordia curve between $1.0 \mathrm{Ga}$ and $0.5 \mathrm{Ga}$, and the intermediate ages are geologically meaningless and probably represent mixtures.

Alternatively, it is possible that the 736 to $837 \mathrm{Ma}$ ages reflect distinct phase in the $\mathrm{P}-\mathrm{T}$ evolution. In this context, it is interesting to note that a $\mathrm{Sm}-\mathrm{Nd}$ mineral isochron age of 809 to 825 Ma was reported for garnet-bearing assemblages in basement gneisses of the northern Prince Charles Mountains, East Antarctica (Hensen and Zhou, 1997). Nichols and Fahey (1996) also reported a Th-Pb monazite age of ca. 800 Ma from a mylonite located at Wall Peak, suggesting mylonite development at this time, and the existence of a high-grade event in the western Prince Charles Mountains. The similar ages obtained on zircons may be interpreted as supporting evidence that a distinct geological process affected the study area at that time. Some concordant zircons that spread along Concordia are most likely a result of multistage growth. We therefore prefer to explain these data as mixed ages. The analytical spots reflect complex zircon structures. Additionally, highly luminescent rims, although too narrow to be analyzed, probably represent a reaction zone that formed during the late Pan-African thermal event.

\section{MAFIC GNEISS}

2.1. Sample 93122-15 (mafic granulite, Fold Island).-Zircons from sample 93122-15 consist predominantly of a $200 \mu \mathrm{m}$ size fraction. The grains are clear, but some are pale yellow. CL images revealed sector zoning, but occasionally fractured and surrounded by a thin high-luminescent rim. The zircons are anhedral with variable shapes from rounded with broad sector zoning to more elongate with parallel zoning. No cores were identified. Representative CL images are presented in figure 5.

Twenty-nine spots were analyzed on 27 grains, and the data are reported in table 4 and are shown on a conventional Concordia diagram (fig. 6A). The concordant to near-concordant data at ca. $1.0 \mathrm{Ga}$ form a statistically coherent population at $978 \pm 7$ $\mathrm{Ma}(\mathrm{MSWD}=2.2 ; \mathrm{n}=24$ ) (fig. 6A). Most grains show no major age difference except for spots 6.1 and 21.1. Three analyses of the bright rims are near concordant (fig. 5A), the bright rim spots (5.1 and 27.2) yielded ages near $959 \mathrm{Ma}$, the bright rim spot 12.1 produced a near-concordant age of $878 \mathrm{Ma}$. The internal structures (fig. 5A) consist of broad parallel zoning common to many diorites and gabbros. The mean age of $978 \pm 7$ $\mathrm{Ma}$ is interpreted to reflect the timing of mafic magmatism, and furthermore there are bright rims that appear to be slightly younger (see fig. 5A) and may indicate the timing of metamorphism. No zircon recrystallization or new growth occurred during the 530 Ma event.

2.2 Sample F129-1 (mafic granulite, Steinnes Peninsula).-The sample contains lightbrown, round to short prismatic, partly irregular zircons, some with crevasses, and are predominantly of a 200 to $300 \mu \mathrm{m}$ size fraction. Most zircons show a distinctly striped character under CL (fig. 5B), whereas some have an outer zone of high luminescence, indicative of low-U-concentration, which may indicate a reaction zone.

Thirty spots on 28 zircons were analyzed (fig. 5B, table 5), and the analyses cluster around the concordia curve, yielding a weighted mean ${ }^{207} \mathrm{~Pb} /{ }^{206} \mathrm{~Pb}$ age of $1007 \pm 10$ 


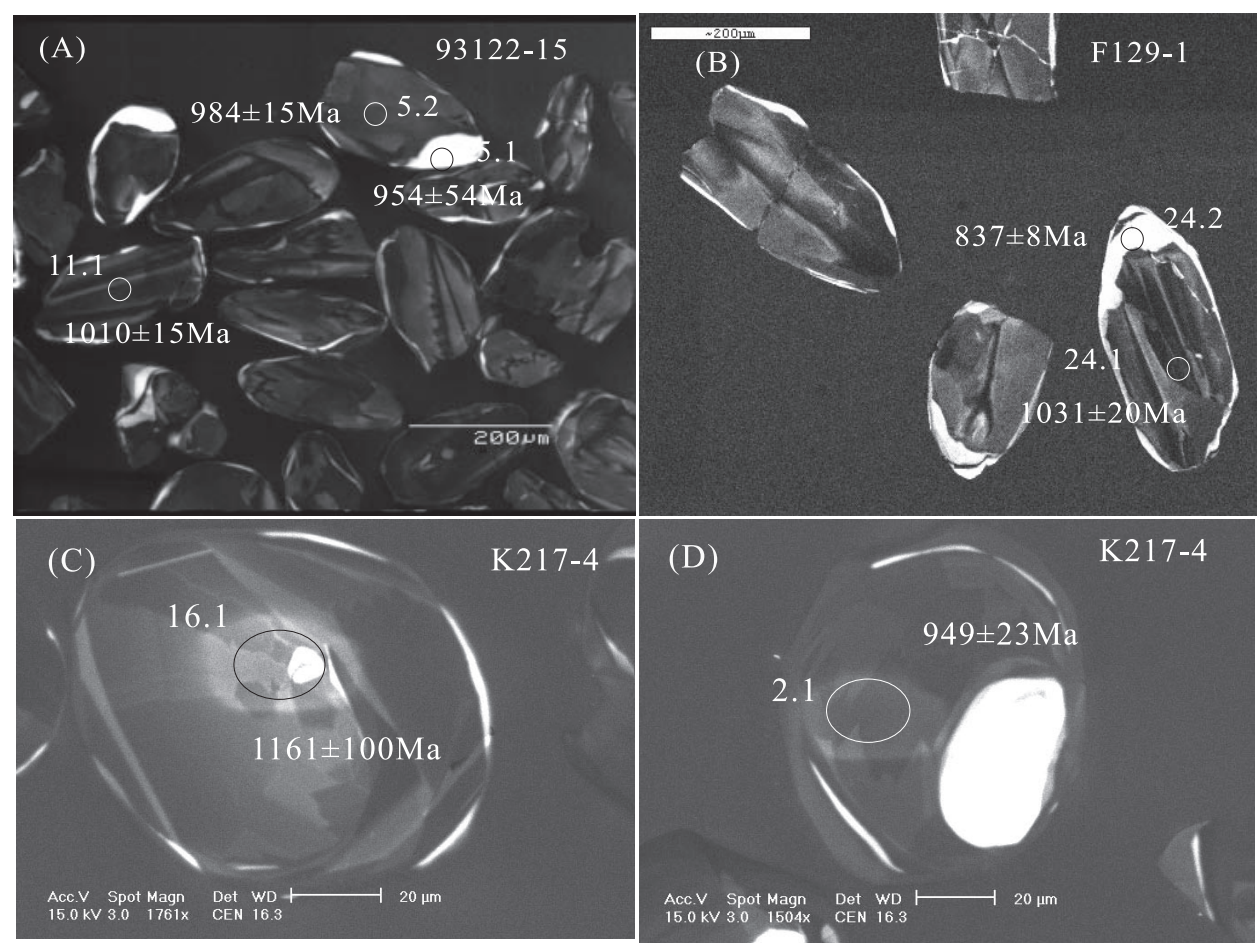

Fig. 5. Characteristic CL images of analyzed zircons from mafic gneiss samples. Numbered ellipsoids indicate SHRIMP analyses. (A) Image of zircon from mafic gneiss sample 93122-15. (B) Image of zircons from mafic gneiss sample F129-1. (C) and (D) Metamorphic zircon overgrowth at ca. 950 Ma indicates timing of Grenville-age metamorphism (K217-4). High-CL reveals inherited low U cores.

Ma $(\mathrm{MSWD}=0.91 ; \mathrm{n}=14)$, which resembles that of sample 93122-15. This age is favored to reflect the timing of mafic magmatism. Minor early Paleozoic Pb-loss caused some data points to plot below the Concordia curve, but there is no indication of a strong ca. 530 Ma event.

2.3 Sample K217-4 (mafic gneiss, Kolloy Island). - This sample contains clear to light-brown, isometric and round zircons consisting predominantly of a $80 \mu \mathrm{m}$ size fraction. Many zircons show highly luminescent cores under CL. Zircon overgrowth in the sample is stubby with internal fir-tree zoning (figs. 5C and 5D), these zircons often have wide high-U rims ( $U$ content from 200 to $1558 \mathrm{ppm}$ ), and a few zircons show typical narrow, highly luminescent low-U rims, too thin to be analyzed on SHRIMP.

Seventeen areas on 16 grains were analyzed (table 6; fig. 6C). The discordant core ages are Mesoproterozoic $\left({ }^{207} \mathrm{~Pb} /{ }^{206} \mathrm{~Pb}\right.$ minimum ages range from 1090 to $\left.1221 \mathrm{Ma}\right)$, whereas the overgrowth analyses yielded a spread in ages from 867 to $1000 \mathrm{Ma}$ along concordia, although there is some scatter along the concordia line. Two spots from typical grains 2.1 and 3.1 with metamorphic rims yielded 96 percent and 99 percent concordant ${ }^{207} \mathrm{~Pb} /{ }^{206} \mathrm{~Pb}$ ages of $949 \pm 37 \mathrm{Ma}$ and $906 \pm 64 \mathrm{Ma}$ respectively. Some analyses plot on or slightly below Concordia, but a few plot above Concordia, probably due to gain of radiogenic $\mathrm{Pb}$ during metamorphic disturbance (for example, Williams and others, 1984). The data cluster mainly around ages of 850 to $1000 \mathrm{Ma}$ (fig. 6C). The highly luminescent rims probably indicate resorption or dissolution/reprecipitation during the early Paleozoic. Therefore, we argue that metamorphic zircon growth occured at $\sim 900$ to $950 \mathrm{Ma}$. 
586 Y. Wang and others—Shrimp zircon age constraints from the Larsemann Hills region,

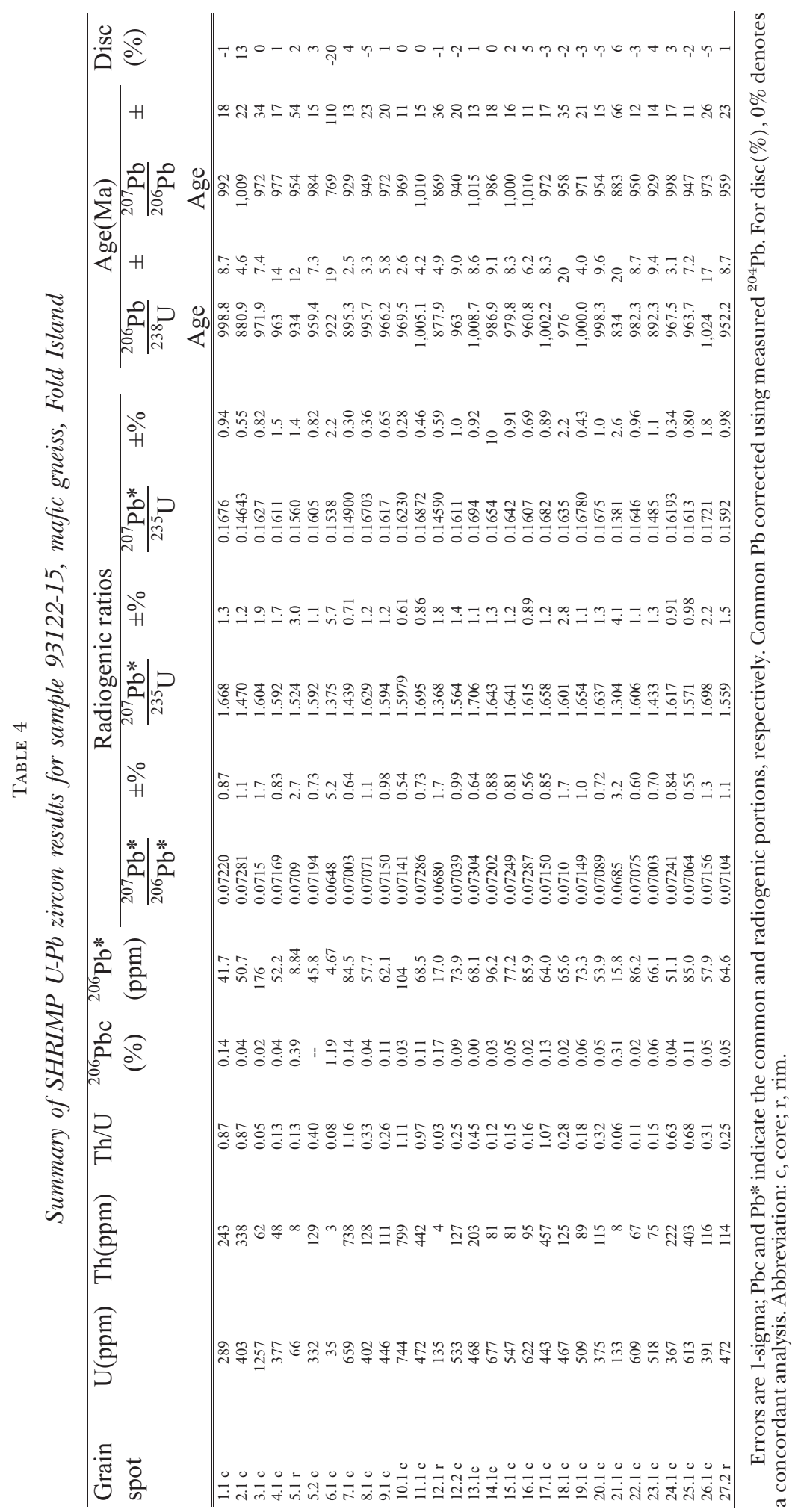



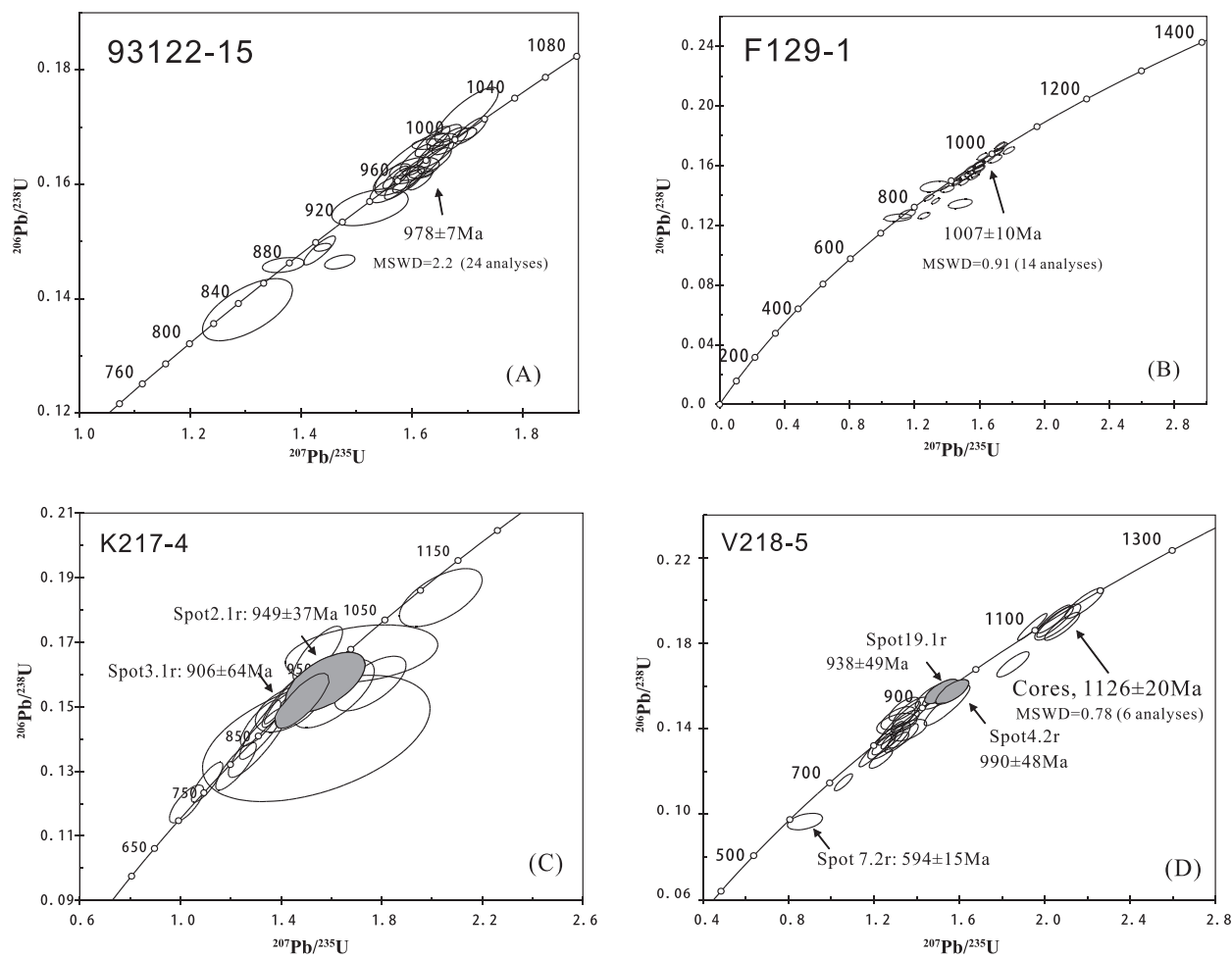

Fig. 6. Concordia diagrams for four zircon samples of the mafic gneiss, indicating Grenville-age metamorphism at ca.1.0 Ga and a Pan-African overprint at ca. $0.53 \mathrm{Ga}$. Error ellipses are $1 \sigma$.

2.4 Sample V218-5 (mafic granulite, Vögoy Island).-Zircons are brown and 100 to $280 \mu \mathrm{m}$ long, with rounded metamorphic overgrowth. CL images show that many grains contain zoned magmatic cores, overgrown by metamorphic zircon (fig. 7). These CL images are strikingly different from samples 93122-15, F129-2 and K217-4 and imply that the mafic gneiss is possibly derived from a gabbroic protolith. We analyzed 28 spots on 22 grains (fig. 6D, table 7). For the zoned magmatic components, some areas are discordant and have lost radiogenic $\mathrm{Pb}$. Six analyses are nearconcordant and produced a weighted mean ${ }^{207} \mathrm{~Pb} /{ }^{206} \mathrm{~Pb}$ age of $1126 \pm 20 \mathrm{Ma}$ $(\mathrm{MSWD}=0.78)$. This age provides the best estimate for the time of emplacement of the mafic precursor.

Some analyses of the metamorphic overgrowths are characterized by slight discordancy and lost radiogenic $\mathrm{Pb}$. Two spots from typical grains 4 and 19 with metamorphic rims have 95 percent concordant ${ }^{207} \mathrm{~Pb} /{ }^{206} \mathrm{~Pb}$ ages of $990 \pm 48 \mathrm{Ma}$ and $938 \pm 49 \mathrm{Ma}$ (fig. 6D). The data indicate igneous crystallization at ca. $1100 \mathrm{Ma}$, followed by resorption and new metamorphic growth at ca. 940 to $990 \mathrm{Ma}$. The rim ages are interpreted to represent a metamorphic overprint, and twelve zircon overgrowth analyses constitute a concordant population with a mean ${ }^{206} \mathrm{~Pb} /{ }^{238} \mathrm{U}$ age of $854 \pm 13 \mathrm{Ma}(\mathrm{MSWD}=1.7)$. This, however, is interpreted to represent a mixed age. From CL images we conclude that substantial new zircon growth must have occurred twice (at $1.0 \mathrm{Ga}$ and $\sim 0.53 \mathrm{Ga}$ ) around pre-existing grains. Progressive recrystallization in some zircon grains may be partial, leaving a "memory" of the previous isotopic composition (figs. 7A and 7B). Isotopic analysis of such an area will yield an age older 
588 Y. Wang and others—Shrimp zircon age constraints from the Larsemann Hills region,

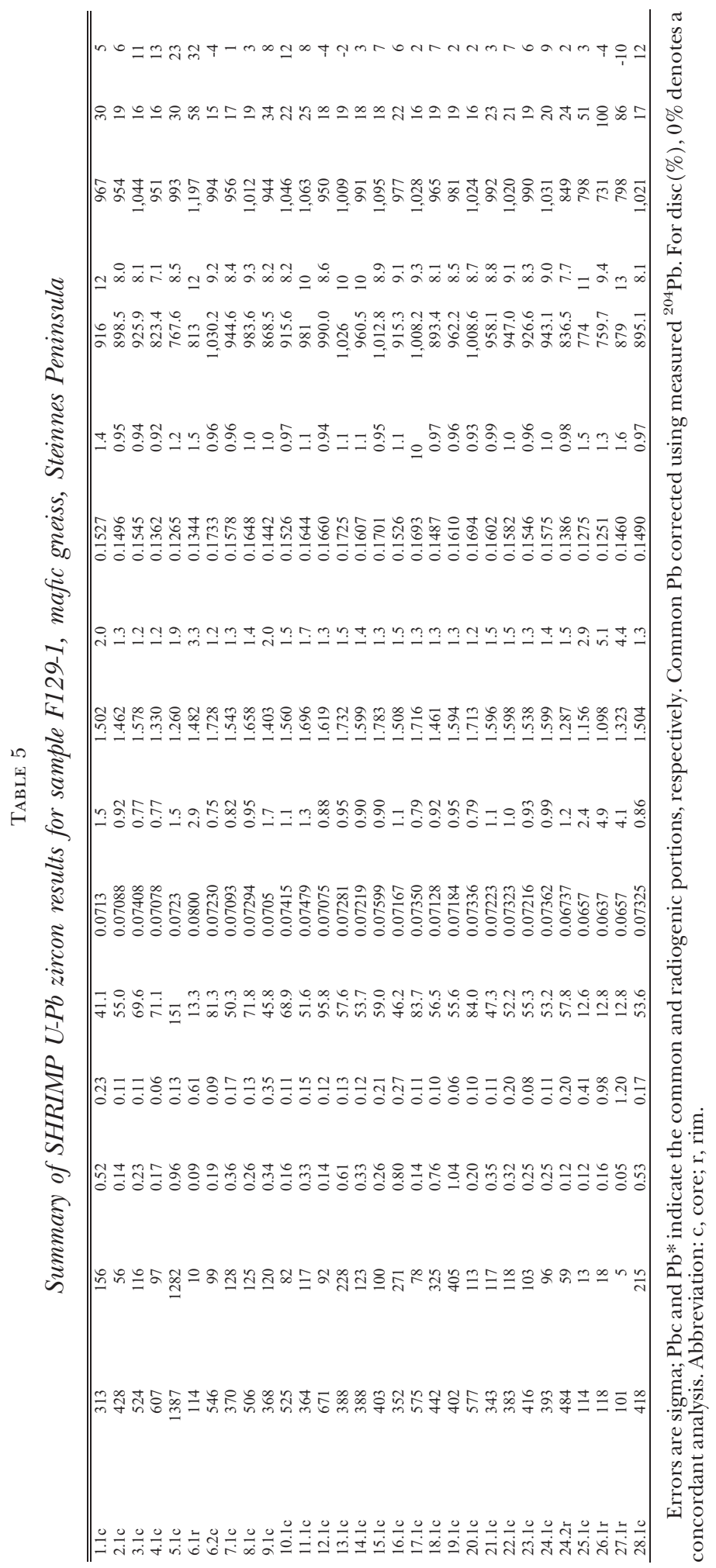




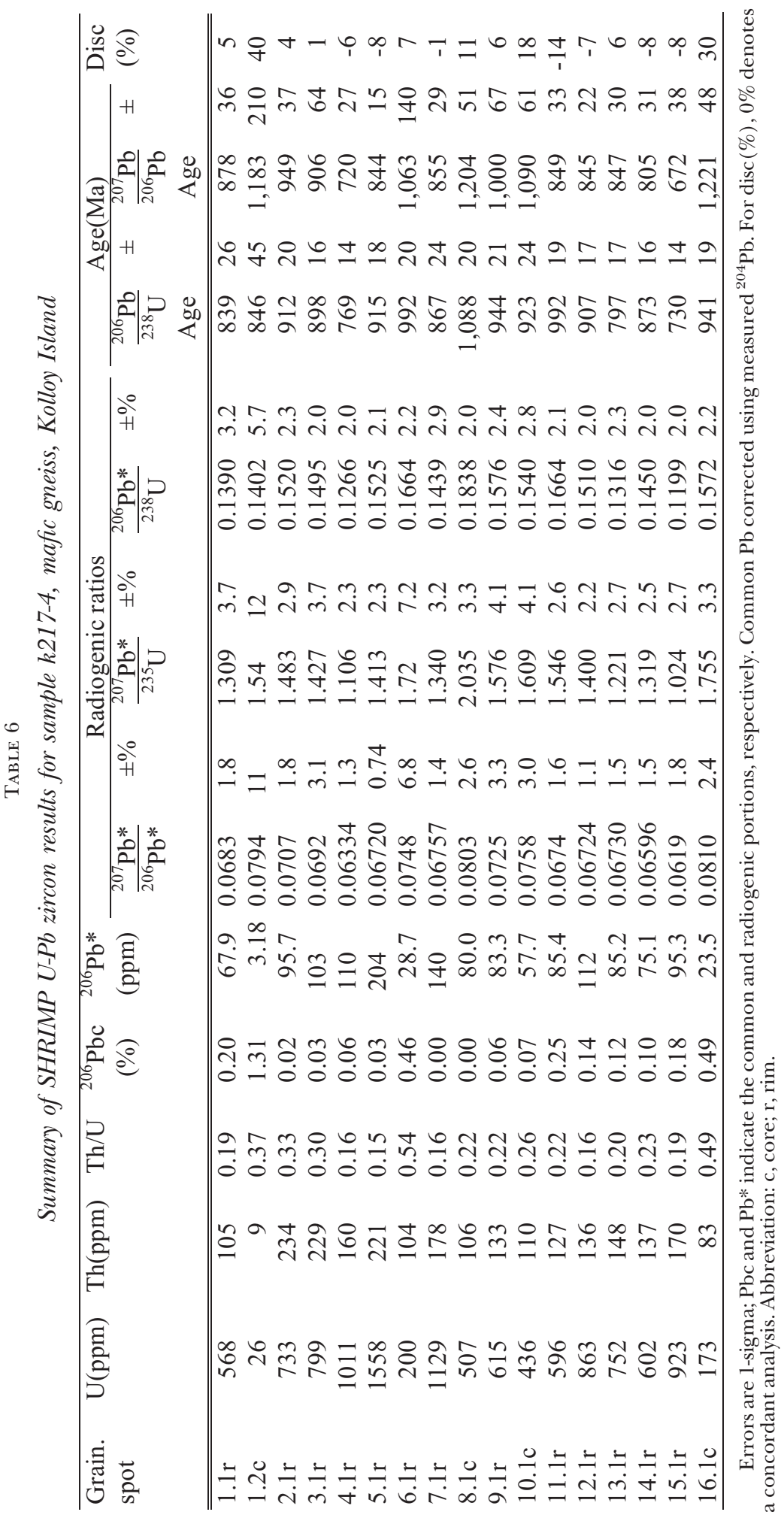



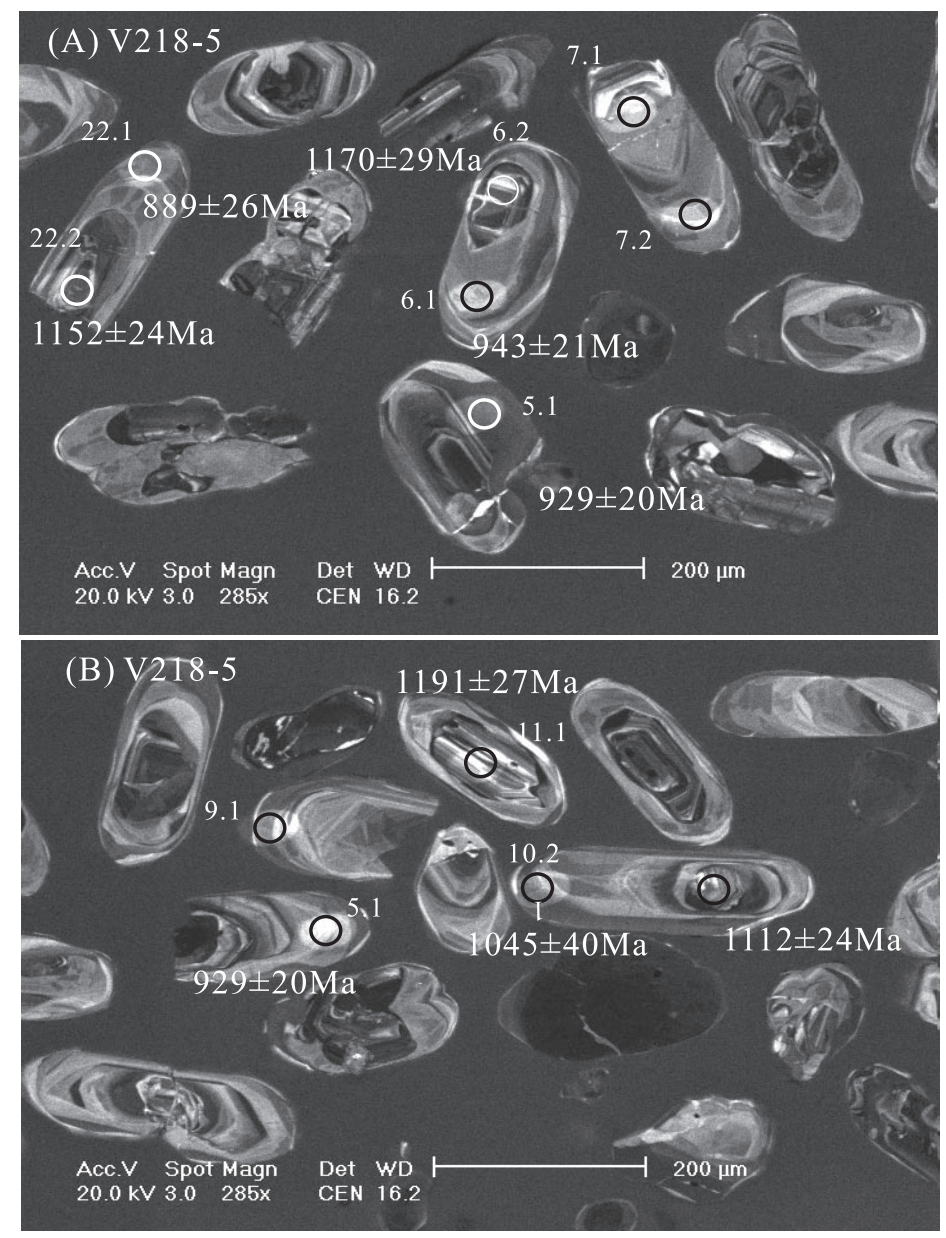

Fig. 7. Cathodoluminescence images of typical zircons from mafic gneiss sample V218-5, displaying inherited cores and broad rims.

than the event inducing late recrystallization and younger than the early magmatic zircon (Hoskin and Black, 2000). The data points plot along the concordia line between 1.0 and $0.5 \mathrm{Ga}$, and the ages are therefore considered geologically meaningless.

Alternatively, it is possible that the ca. 854 Ma date marks the time of a distinct phase in the P-T evolution. The explanation is the same as for mafic gneiss sample K217-3, but different from samples 93122-15 and F129-2. This suggests that these rocks have different protoliths. Sample V218-5 probably originated from a gabbroic intrusive rock, whereas the occurrence and mineral assemblages suggest that samples 93122-15 and F129-2 were probably derived from dismembered mafic dikes (Dirks and others, 1993; Wang and others, 1994). In fact, the presence of a tight cluster of ages at $854 \mathrm{Ma}$ is hard to explain merely as a result of two-stage overprinting - one would expect more of a smear given that ca. $990 \mathrm{Ma}$ rims also occur. This "age" is intriguing and requires further testing. 


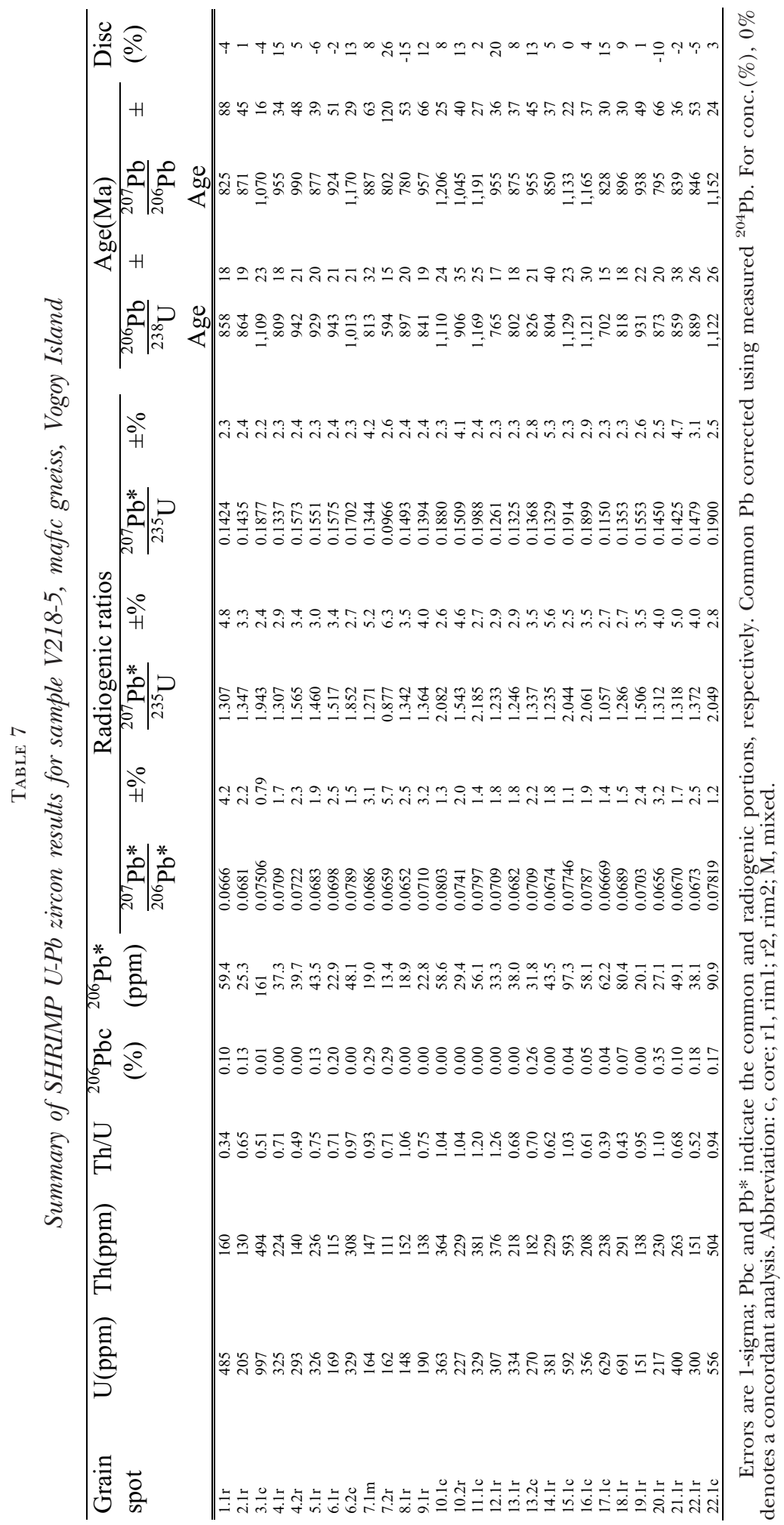




\section{PARAGNEISS}

3.1 Sample 981227-1 (metapelite, Seal Cove of the Mirror Peninsula).-All zircon grains are relatively large, 200 to $250 \mu \mathrm{m}$ in length, and have the rounded forms common to zircons from high-grade rocks, and many grains are ellipsoidal to spherical. CL imaging shows that most grains contain inherited cores with oscillatory zoning, characteristically surrounded, in whole or in part, by a thin, structureless, weakly luminescent overgrowth (rim1) (figs. 8A, 8B, 8C and 8D). Each zircon also exhibits a thin outer rim (rim2) with relatively bright luminescence in CL images.

$\mathrm{U}-\mathrm{Th}-\mathrm{Pb}$ analyses of the zircons are listed in table 8 and plotted on the Concordia diagram of figure 9A. The cores with magmatic growth zoning are a little heterogeneous in composition, both chemically and isotopically. U-contents range from 245 to $677 \mathrm{ppm}$, and $\mathrm{Th} / \mathrm{U}$ range from 0.07 to 0.42 . Twelve of the analyzed grains consist of oscillatory-zoned cores that give ${ }^{207} \mathrm{~Pb} /{ }^{206} \mathrm{~Pb}$ ages ranging from 1034 to $1769 \mathrm{Ma}$, with a main age peak at ca. $1.1 \mathrm{Ga}$. This confirms that the zircon cores are detrital in origin from a late Paleoproterozoic to Mesoproterozoic provenance. No Archean grains were detected. The issue for this sample is whether the range in ages reflects erosion from a wide range of sources (that is, a paragneiss), or whether the age range was produced through variable $\mathrm{Pb}-\mathrm{loss}$ from an igneous protolith (that is, an orthogneiss). Given the zircon ages alone the paragenesis of this sample (that is, sedimentary vs. magmatic origin) is difficult to establish. The presence of a Paleoproterozoic age is indicative of sedimentary input (though it represents a very small fraction of the material analyzed) and an apparent age peak at $1.1 \mathrm{Ga}$. However, this peak is similar to that of the felsic gneiss samples, which are interpreted as orthogneisses. Because of the extensive production of metamorphic rims in this rock, it is likely that at least some disturbance in the U-Pb system has occurred. The age data imply that the source of the paragneiss sequence is possibly a felsic to intermediate igneous rock.

The overgrowths (rim 1) have a wide range in $\mathrm{U}(368-1765 \mathrm{ppm})$ and low $\mathrm{Th} / \mathrm{U}$ (mostly $0.02-0.07$ ). Such extreme $\mathrm{Th} / \mathrm{U}$ values are a feature of zircons crystallizing at high metamorphic grade (Williams and others, 1996). The overgrowth analyses (that
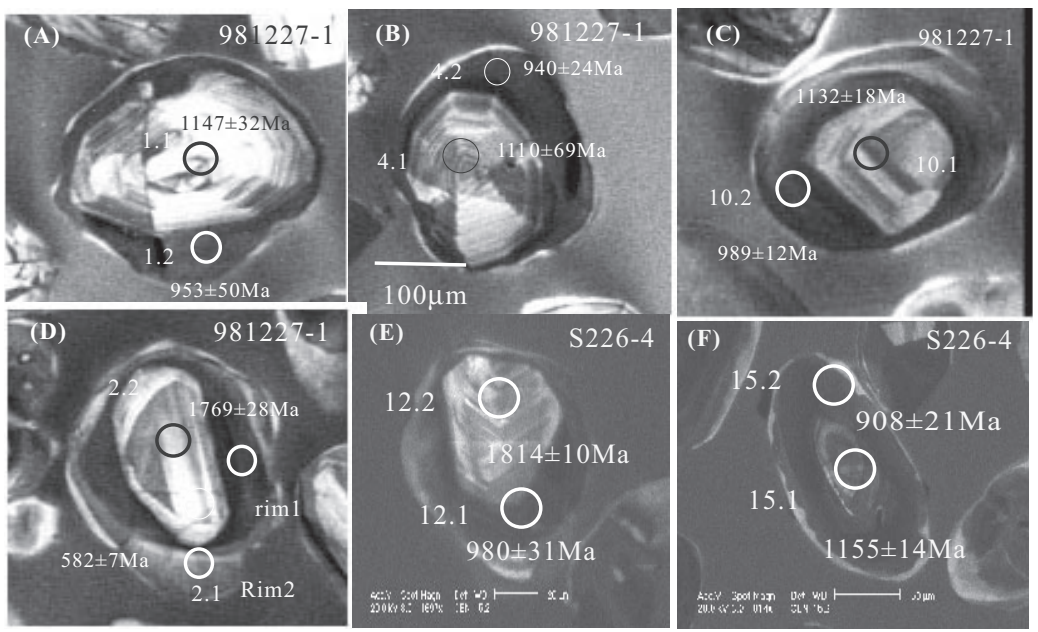

Fig. 8. Detrital zircon grains with metamorphic overgrowths of varying width from metasedimentary samples. A, B, C and D from Seal Cove; CL image of inherited magmatic core with a small-volume isometric high-U zircon rim; typical zircons have a very thin, highly luminescent rim that is probably indicative of metamorphic resorption of Pan-African age. Scale bars are $100 \mu \mathrm{m}$. Grain identification numbers include SHRIMP spot number and ages; E and F from south of Nella Fjord. 


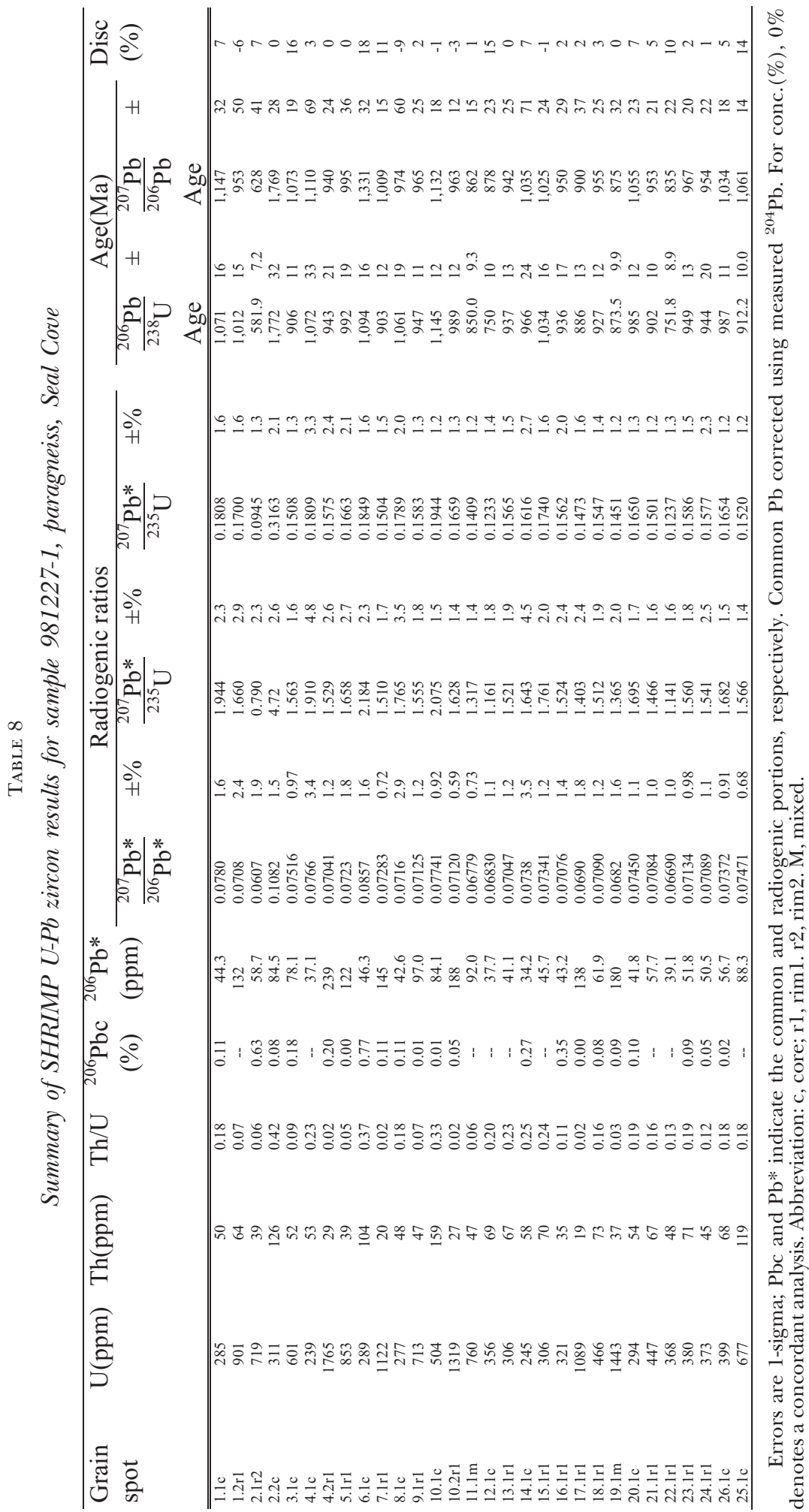



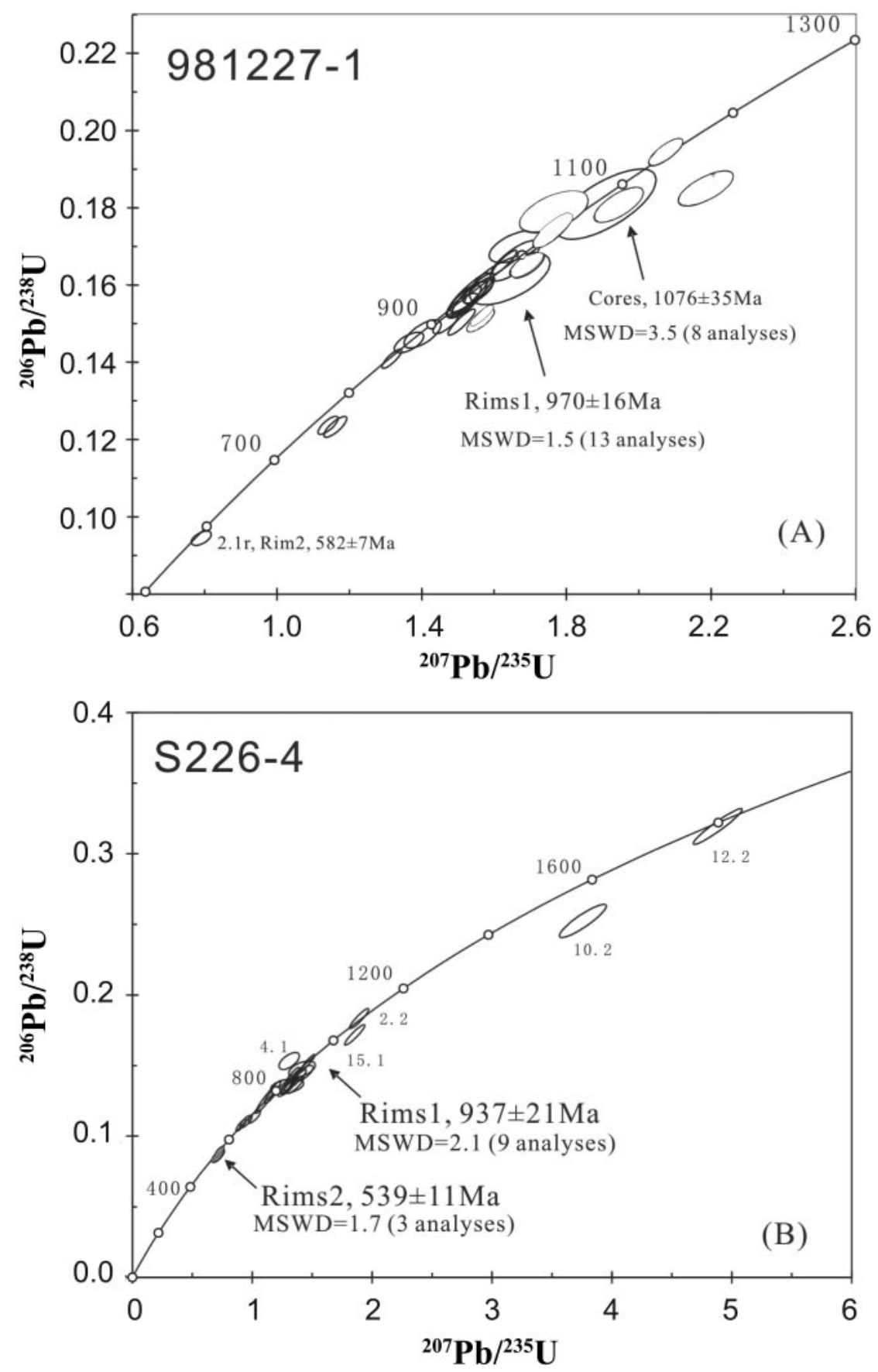

Fig. 9. Concordia diagram for two metasedimentary zircon samples from Seal Cove and south of Nella Fjord, Mirror Peninsula. Error ellipses are $1 \sigma$. 
is, spots $4.2,5.1,13.1,15.1,24.1)$ cluster near Concordia at ca. 1.0 Ga (fig. 9A). Thirteen analyses give a weighted mean ${ }^{207} \mathrm{~Pb} /{ }^{206} \mathrm{~Pb}$ age of $970 \pm 16 \mathrm{Ma}(\mathrm{MSWD}=1.5$; fig. 9A). It is possible that the paragneisses were deposited $<1000 \mathrm{Ma}$ but contain polyphase detrital zircons that record pre-depositional ages of $1130 \mathrm{Ma}$ and/or 1000 Ma. The exceptions are the spots with mixed analyses. The outer rim 2 was analyzed in one zircon and yielded a ${ }^{206} \mathrm{~Pb} /{ }^{238} \mathrm{U}$ age of $582 \pm 7 \mathrm{Ma}$.

3.2. Sample S226-4 (paragneiss, Seal Cove of the Mirror Peninsula).-The zircons are round and stubby, elongate, have round to subrounded terminations, with three textural types (core, rim 1, and rim 2) distinguished (figs. 8E and 8F). They consist predominantly of a 60 to $80 \mu \mathrm{m}$ size fraction. The cores have a moderate CL response and show oscillatory zoning (that is, spot 12.2). They are surrounded by multiple overgrowths. The first (innermost) overgrowth (rim 1) is usually high in $U(\sim 1000$ ppm), and is only developed around a few cores. Rim1 has a low CL response and commonly is more homogeneous, it also occurs as wide overgrowth on Mesoproterozoic cores (fig. 8E, spot 12.1). Rim1 shows an absence of oscillatory zoning, consistent with metamorphic growth. The outer rim 2 is composed of a medium- $U$ generation.

Twenty-four analyses were performed on sixteen grains (table 9 and fig. 9B). Four analyses of oscillatory-zoned cores $(10.2,12.2,2.2,15.1)$ give Paleoproterozoic to Mesoproterozoic ${ }^{207} \mathrm{~Pb} /{ }^{206} \mathrm{~Pb}$ ages of $1765 \pm 17,1814 \pm 10,1065 \pm 14,1155 \pm 14 \mathrm{Ma}$ respectively. Uranium concentrations range from 221 to $921 \mathrm{ppm}$, Th from 152 to 337 $\mathrm{ppm}$, and $\mathrm{Th} / \mathrm{U}$ ratios from 0.35 to 0.97 . The systematics of S226-4 are therefore similar to 981227-1 of Seal Cove. The zircon cores are interpreted as detrital grains and yielded diverse ages. The discordant nature of some core analyses probably reflects $\mathrm{Pb}-$ loss during metamorphism, the ${ }^{207} \mathrm{~Pb} /{ }^{206} \mathrm{~Pb}$ ages generally range from 1.8 to $1.1 \mathrm{Ga}$ (fig. 9B), also consistent with the detrital signature from sample 981227-1.

Nine analyses were made of type 1 rims, which have $U$ contents between 498 and $1440 \mathrm{ppm}$ and $\mathrm{Th} / \mathrm{U}$ ratios between 0.02 and 0.08 . These rims yielded ${ }^{207} \mathrm{~Pb} /{ }^{206} \mathrm{~Pb}$ ages ranging from $916 \pm 57$ to $997 \pm 22 \mathrm{Ma}$. The discordant ages probably indicate Pb-loss during the second period of zircon overgrowth, mixtures of metamorphic overgrowths and older core material, and/or multiple periods of metamorphic growth. Rim 2 was analyzed in four zircons, one older outlier was rejected (9.1), and a weighted mean of the remaining ${ }^{206} \mathrm{~Pb} /{ }^{238} \mathrm{U}$ ages is $539 \pm 11 \mathrm{Ma}$ (MSWD $=1.7,3$ analyses).

3.3. Sample V218-4 (paragneiss, Vögoy Island). - Zircon fluoresces yellow in transmitted light. Grains are typically rounded, with aspect ratios of 1:1 to 1:2, and range from 100 to $150 \mu \mathrm{m}$ in length. Transmitted light and CL imaging shows oscillatory-zoned cores with wide, homogeneous overgrowths up to $50 \mu \mathrm{m}$ wide (fig. 10). The cores have relatively high $\mathrm{Th} / \mathrm{U}$ ratios (from $0.17-2.49$ ), indicating a magmatic origin, whereas the wide rims have low $\mathrm{Th} / \mathrm{U}$ ratios $(0.02-0.09)$, typical of metamorphic overgrowth. In many cases, for example grain 11 (fig. 10), the rims have an outer zone of relatively bright luminescence, indicative of medium U-concentration, which may indicate a reaction zone.

Eighteen spots from cores and rims were analyzed in 14 zircons (table 10, fig. 11). Eleven analyses of oscillatory-zoned grains give ${ }^{207} \mathrm{~Pb} /{ }^{206} \mathrm{~Pb}$ ages ranging from Paleoproterozoic $(2173 \pm 8 \mathrm{Ma})$ to Mesoproterozoic $(1110 \pm 55 \mathrm{Ma})$ and with significant peaks at ca. 1.1 to $1.2 \mathrm{Ga}$. The implication is that the depositional age of the protolith is $<1110 \mathrm{Ma}$. Seven analyses of the metamorphic rims provide an early Neoproterozoic age record; three zircon rims $(14.1,15.1,17.2)$ confirm a late Grenvillian-age event with ${ }^{207} \mathrm{~Pb} /{ }^{206} \mathrm{~Pb}$ ages of $901 \pm 78 \mathrm{Ma}, 948 \pm 33 \mathrm{Ma}, 945 \pm 98 \mathrm{Ma}$, respectively (table 10 and fig. 11). A typical metamorphic rim analysis of spot 11.2 yielded a ${ }^{207} \mathrm{~Pb} /{ }^{206} \mathrm{~Pb}$ age of $1111 \pm 19 \mathrm{Ma}$, whereas the core analysis of spot 11.1 is $1655 \mathrm{Ma}$ (fig. $10)$. The early Neoproterozoic new zircon growth suggests that a metamorphic episode occurred at ca. $1 \mathrm{Ga}$. These rims have an outer zone, although too thin $(<10 \mu \mathrm{m})$ to 
596 Y. Wang and others—Shrimp zircon age constraints from the Larsemann Hills region,

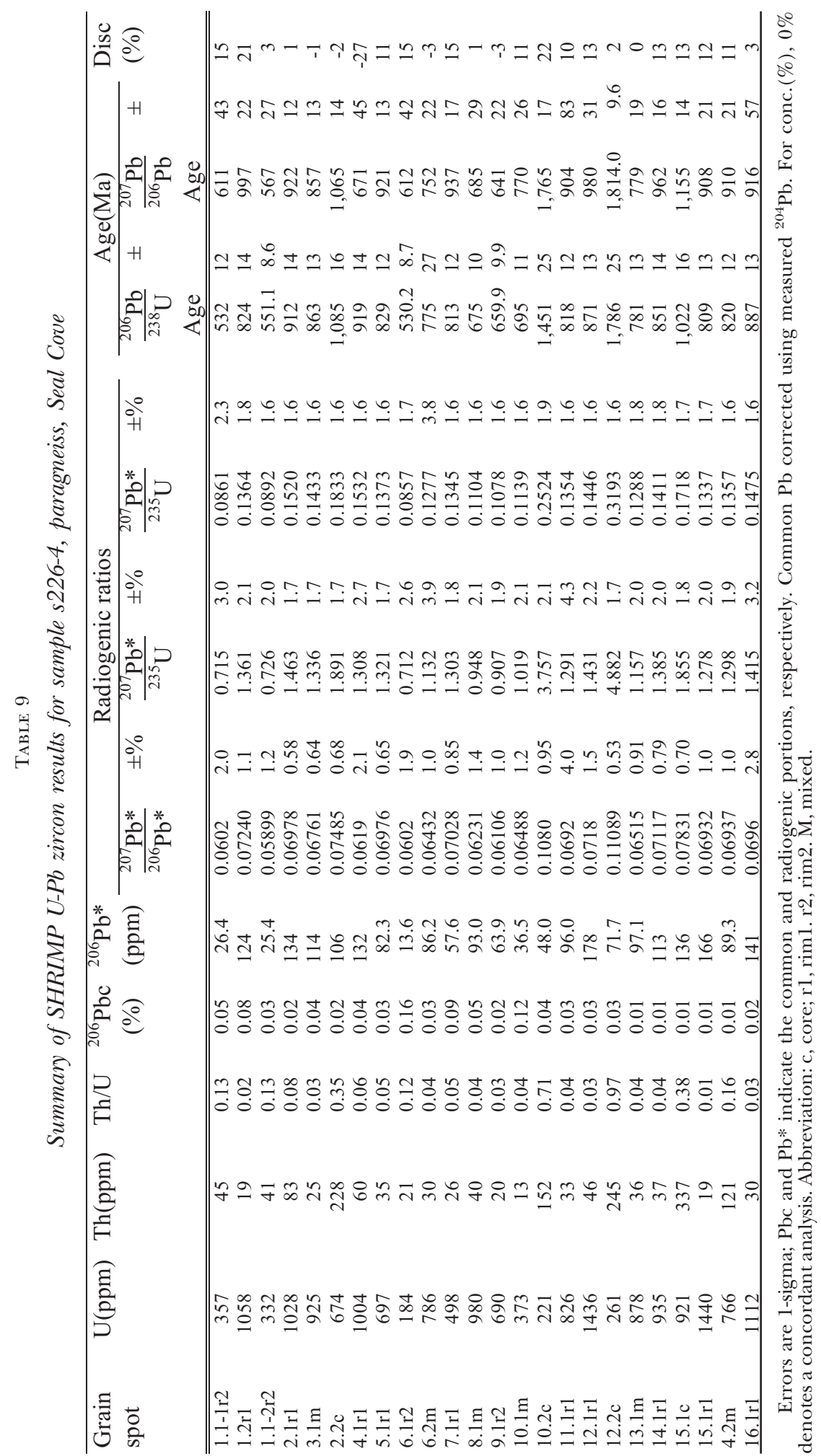




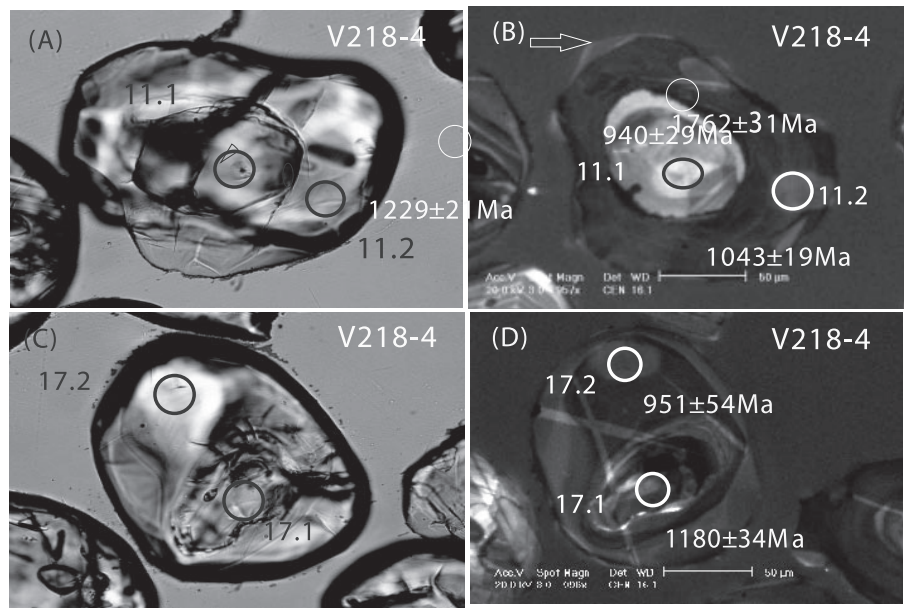

Fig. 10. Characteristic images of analyzed zircons from Vogöy Island metasedimentary sample V218-4. (A) Transmitted light image of core-rim textured zircon grain 11. (B) CL image of zircon grain 11 showing dark Grenville-age metamorphic rim, overgrown on detrital core derived from 1.8 Ga Paleoproterozoic igneous zircon. (C) Transmitted light image of core-rim texture in zircon grain 17. (D) CL image of zircon grain 17; note wide, high-U metamorphic overgrowth around inherited core.

be analyzed, possibly representing an early Paleozoic reaction zone that formed during late geological processes. The discordant nature of some rim analyses probably reflects Pb-loss during early Neoproterozoic and early Paleozoic metamorphism, or mixed compositions between the two overgrowth zones.

\section{ENDERBITE}

4.1 Sample 981221-2 (enderbite, Grovness Peninsula).-The zircons from this sample form a homogeneous assemblage of slightly elongated, prismatic grains with curvilinear to blunt terminations. Zircons consist predominantly of a $300 \times 60 \mu \mathrm{m}$ size fraction and are clear with well developed magmatic growth zoning. CL shows oscillatory zoned zircon cores (fig. 12) which typically have U-concentrations between $\sim 230$ and 1150 ppm. These cores often show strong marginal resorption and are surround by metamorphic overgrowth (fig. 12B).

Forty spots were analyzed on thirty-eight grains from sample 981221-2, concentrating on areas exhibiting growth zoning as revealed by CL imaging. A mean ${ }^{207} \mathrm{~Pb} /{ }^{206} \mathrm{~Pb}$ age of $971 \pm 17 \mathrm{Ma}$ (MSWD=2.5, 15 analyses) obtained for these zircon cores represents the intrusion age of the enderbite (fig. 13A, table 11). Some analyses provided discordant ages, probably indicating Pb-loss during zircon overgrowth. The metamorphic overgrowth analysis of spot 20.1 yielded a ${ }^{206} \mathrm{~Pb} /{ }^{238} \mathrm{U}$ age of $547 \pm 5 \mathrm{Ma}$.

\section{GRANITIC GNEISS}

5.1 Sample F127-4 (granitic gneiss, south side of Lake Nella, Brokens Peninsula). - This sample contains elongate zircons between 150 and $210 \mu \mathrm{m}$ in length, and CL images show simple magmatic zonation and resorption features, and the latter are attributed to metamorphism. The magmatic cores have medium U-concentrations (185-424 ppm), whereas the thin, structureless, metamorphic overgrowth areas are high in $\mathrm{U}$ and display weak luminescence (fig. 12). Fourteen areas were analyzed, with magmatic cores targeted. The age pattern is shown on the Concordia plot of figure 13B. The analyses (table 12) form a concordant cluster with a mean ${ }^{207} \mathrm{~Pb} /{ }^{206} \mathrm{~Pb}$ age of $1056 \pm$ $24 \mathrm{Ma}$, consistent with the analyses of magmatic cores from sample S204-1. Grains 3.1 
598 Y. Wang and others—Shrimp zircon age constraints from the Larsemann Hills region,

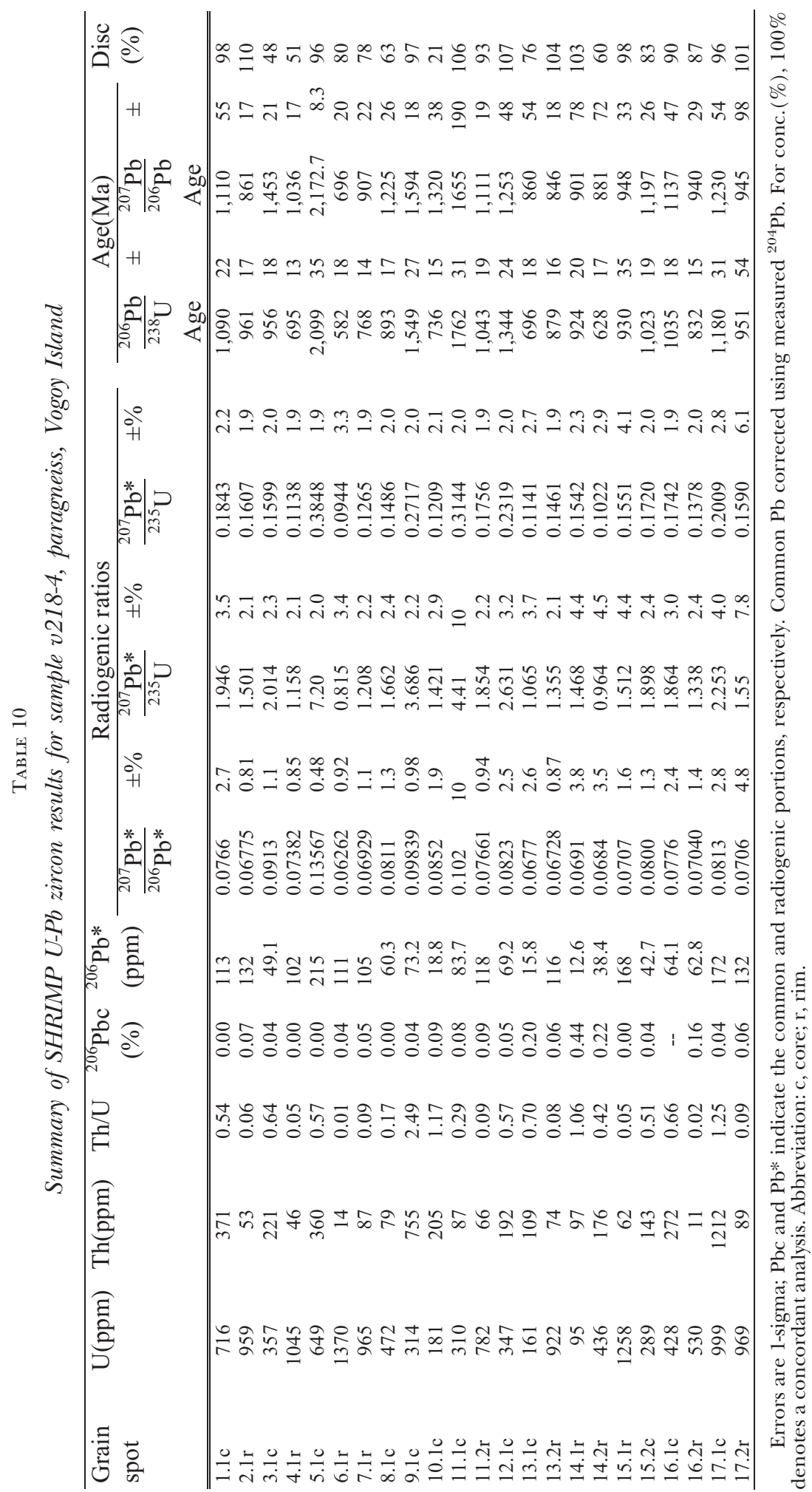




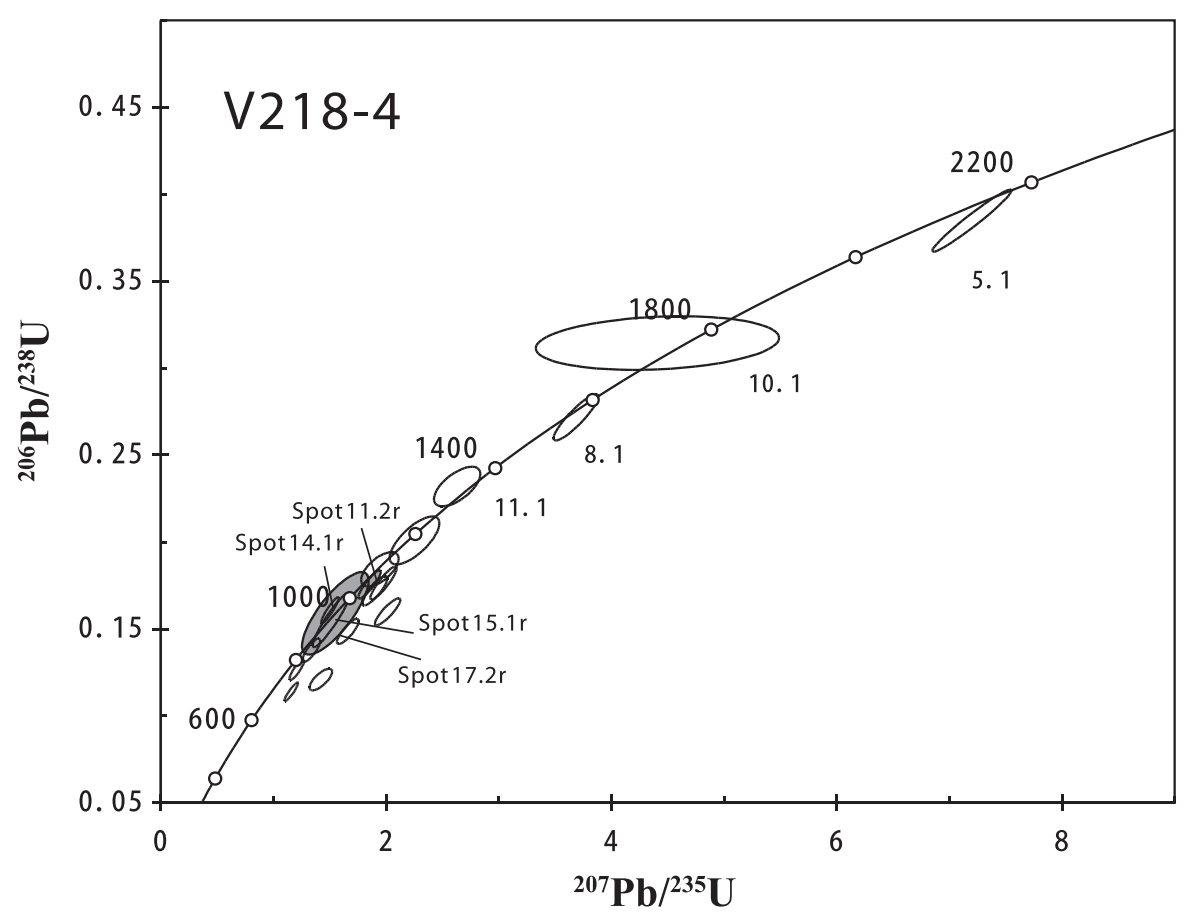

Fig. 11. Concordia diagram of zircon analyses from sample V218-4. The data indicate different degrees of Pb-loss during Grenville-age metamorphism and metamorphic zircon overgrow at ca. 1.0 Ga. Error ellipses are $1 \sigma$.

and 11.1 are strongly discordant and are considered to represent an older, inherited component that lost radiogenic $\mathrm{Pb}$ when the majority of zircon formed around 1000 Ma. Exclusion of these data from the weighted mean provides an age of $1011 \pm 19 \mathrm{Ma}$ $(\mathrm{MSWD}=1.4,12$ analyses $)$, and this is interpreted to represent the intrusion age of the gneiss protolith.

5.2 Sample S204-1 (granitic gneiss, Stornes Peninsula).-The sample contains light brown and yellowish, elongated prismatic zircons, and length-width ratios are usually less than 3 . The sample consists predominantly of a $60 \times 250 \mu \mathrm{m}$ size fraction, and most zircons contain many inclusions. CL-images show oscillatory magmatic growth zoning (figs. $12 \mathrm{E}-\mathrm{F}$ ), and the zircons have U concentrations between 441 and $1699 \mathrm{ppm}$ and $\mathrm{Th} / \mathrm{U}$ ratios of 0.1 to 0.6 .

Twelve areas on 11 zircons were analyzed (table 13), and most analyses represent the main zircon population, scattering at around ca. 1000 Ma. Five analyses show evidence for radiogenic lead loss $(4.1,6.1,9.1$ 11.1). The less dominant age group is represented by analyses 4.1 and 6.1 , and these gave ${ }^{207} \mathrm{~Pb} /{ }^{206} \mathrm{~Pb}$ ages of ca. $1200 \mathrm{Ma}$ and represent zircon core inheritance. Excluding the discordant and inherited ages, the remaining grains of this age group give a weighted mean ${ }^{206} \mathrm{~Pb} /{ }^{207} \mathrm{~Pb}$ age of $1004 \pm 35 \mathrm{Ma}(\mathrm{MSWD}=6.8)$, which is the best estimate for the emplacement age of the granitic gneiss protolith.

One analysis from a rim outside the poorly luminescent zone (8.1) yielded a ${ }^{206} \mathrm{~Pb} /{ }^{207} \mathrm{~Pb}$ age of $942 \pm 13 \mathrm{Ma}$. This young rim has a higher U-concentration than the core, with a $\mathrm{U} / \mathrm{Th}$ ratio of 0.11 ; the high-U rim analysis is therefore interpreted as a result of resorption. 


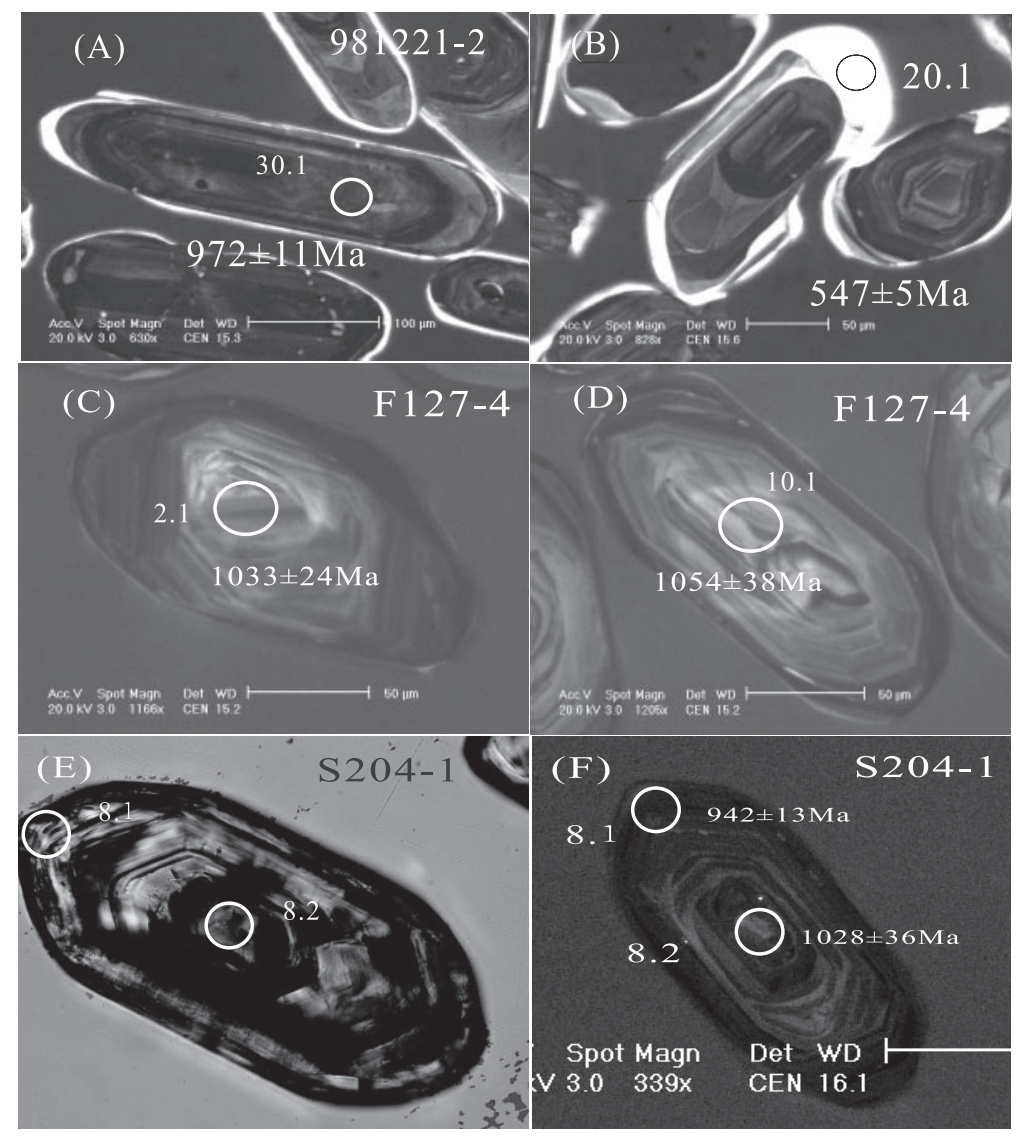

Fig. 12. Representative CL images of zircon structures. (A) and (B) are zircons from enderbite sample 981221 with oscillatory zoned magmatic cores and thin CL-bright overgrowths. (C) and (D) are CL images of sectioned zircons from granitic gneiss sample F127-4 showing a simple zoned magmatic structure. (E) Transmitted light image of grain 8 from granitic gneiss S204-1. (F) CL image of grain 8 with oscillatory zoned magmatic characteristics.

\section{LEUCOGNEISS}

6. Sample 981230 (garnet-bearing leucogneiss, eastern Mirror Peninsula).- - The garnetbearing leucogneiss described by Carson and others (1995) from the same location is named the Zhongshan gneiss. Zhao and others (1995) reported a ${ }^{206} \mathrm{~Pb} /{ }^{207} \mathrm{~Pb}$ zircon age of $940 \pm 6 \mathrm{Ma}$, using the $\mathrm{Pb}-\mathrm{Pb}$ stepwise evaporation technique, and a ca. 1.0 Ga $\mathrm{Rb}-\mathrm{Sr}$ whole-rock isochron age for this rock. They correlate these ages with an intrusion event that pre-dates the deposition of the adjacent metasediments. Dirks and others (1993) suggested that the leucogneiss body was emplaced during the early history of the Larsemann Hills. However, Stüwe and others (1989) interpreted this same leucogneiss as a partial melt derived from the metasediment, whereas Carson and others (1995) argued that it may have a sedimentary origin.

The sample contains small to medium-sized $(60-400 \mu \mathrm{m})$, rounded to elongate and complex zircons. They are yellowish to brownish in color, and CL images show that many grains are high-U (1010-7642 ppm) zircons with $\mathrm{Th} / \mathrm{U}$ ratios of $0.02-0.1$ (fig. 14). In this case the low- $\mathrm{Th} / \mathrm{U}$ ratio is a consequence of magmatic processes giving rise to high $\mathrm{U}$ and relatively low Th during high-grade metamorphism. Due to the high $\mathrm{U}$ 

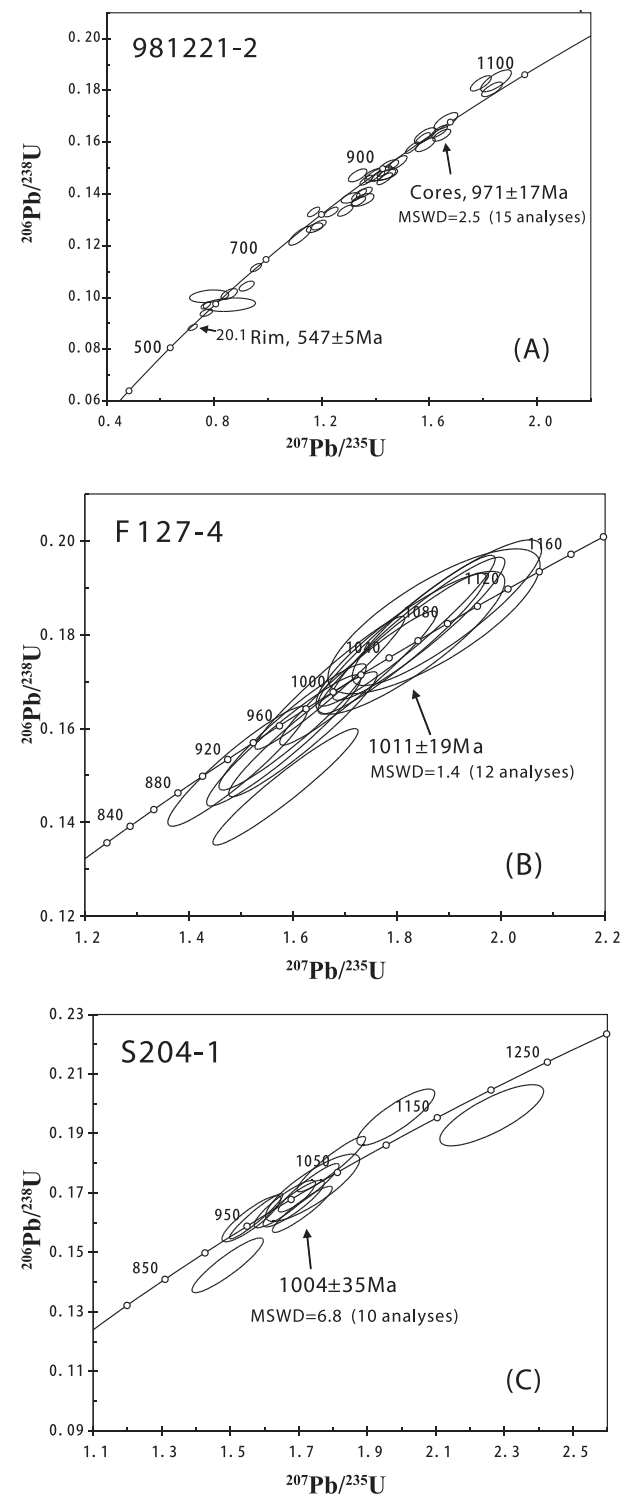

Fig. 13. Concordia diagrams of dated samples. (A) Zircons from enderbite at Grovness Peninsula. (B) Zircons from granitic gneiss near the south of Lake Nella. (C) Zircons from granitic gneiss at Stornes Peninsula. Error ellipses are $1 \sigma$.

concentrations, the ${ }^{204} \mathrm{~Pb}$-corrected analyses are slightly reversely discordant on a standard Concordia plot (fig. 15). This reverse discordancy effect is well known for zircons with $\mathrm{U}$ in excess of $\sim 1000 \mathrm{ppm}$ (Williams and others, 1984). Twenty-six grains from this sample were analyzed (table 14). These zircons show relatively little Pb-loss at $500 \mathrm{Ma}$, and many analyses are concordant within error (fig. 15). The $1025 \pm 12 \mathrm{Ma}$ weighted mean ${ }^{206} \mathrm{~Pb} /{ }^{207} \mathrm{~Pb}$ age is interpreted to reflect crystallization of the zircons in the leucogneiss precursor at the time of intrusion.

Alternatively, the following explanation must be considered: Sample 981230 contains subhedral to round zircons, and the leucogneiss may possibly have been 
602 Y. Wang and others_Shrimp zircon age constraints from the Larsemann Hills region,

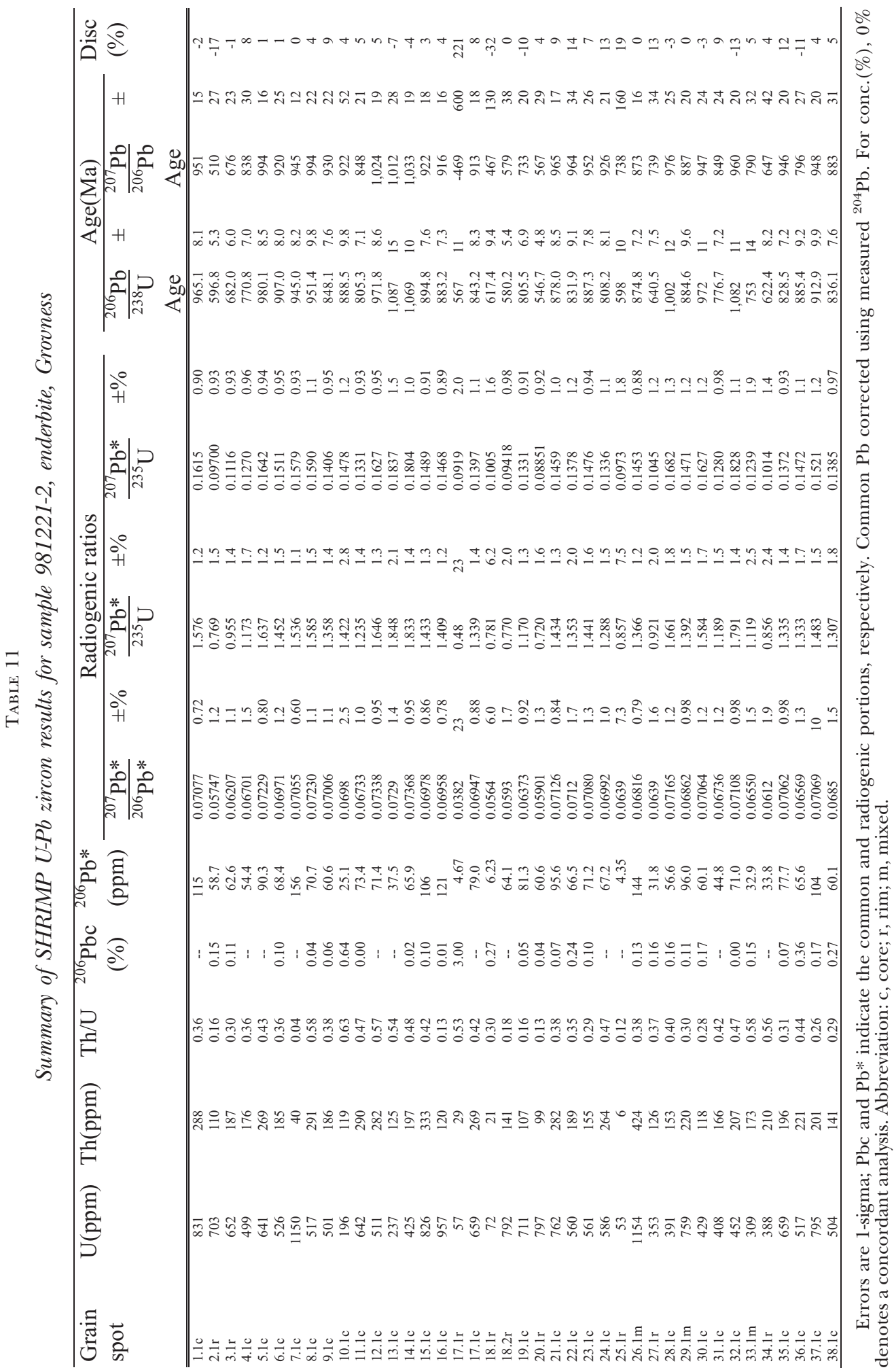




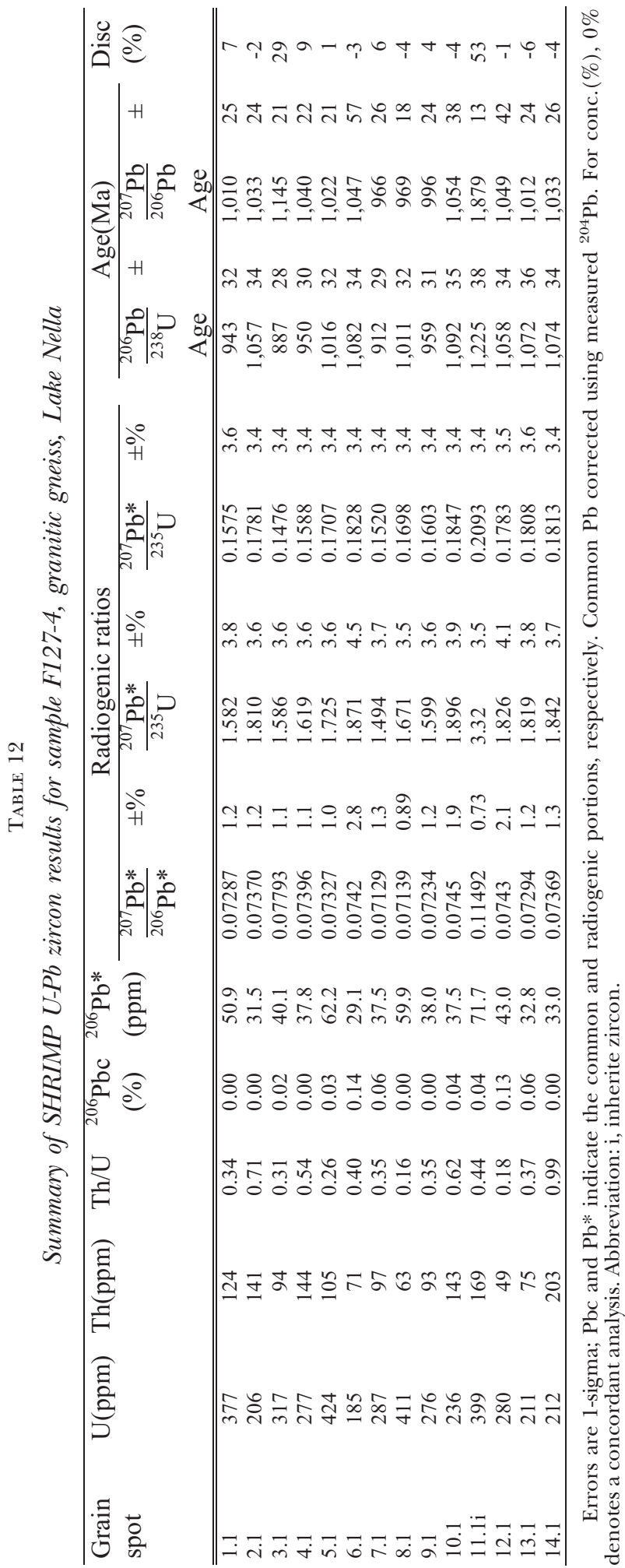


$604 Y$. Wang and others—Shrimp zircon age constraints from the Larsemann Hills region,

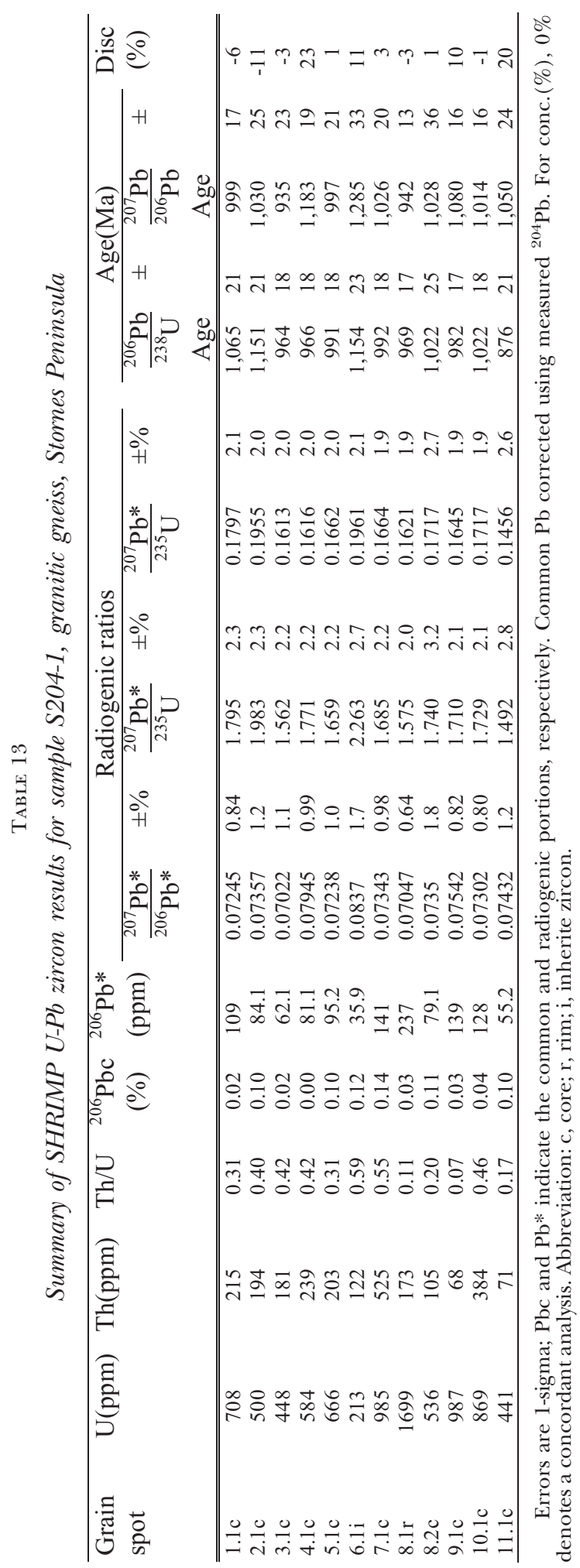




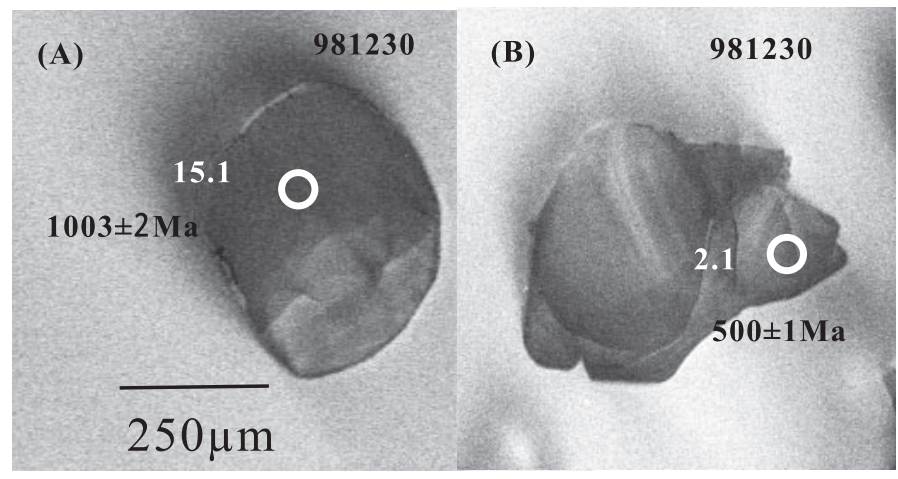

Fig. 14. Cathodoluminescence images and SHRIMP spot analyses of selected zircon grains from leucogneiss rocks from Zhong Shan station. (A): Zircon 15 from sample 981230, showing dark high-U core age of $1.0 \mathrm{Ga}$. (B): Zircon 2 from leucogneiss (981230) showing a 0.5 Ga overgrowth rim.

produced from a high-temperature partial melt (Gilotti and Elvevold, 2002). Low $\mathrm{Th} / \mathrm{U}$ ratios $(0.02-0.1)$ and weak to no zoning in the zircons suggest a metamorphic origin for these grains (Rubatto and Gebauer, 2000).

The presence of very thin metamorphic rims on zircons from the leucogneiss that has undergone a second partial melting event is consistent with the observation that new zircon growth occurred during the early Paleozoic thermal event in the study area. The young rim age of $500 \mathrm{Ma}$ probably reflects the second event of granulite-facies metamorphism and anatexis.

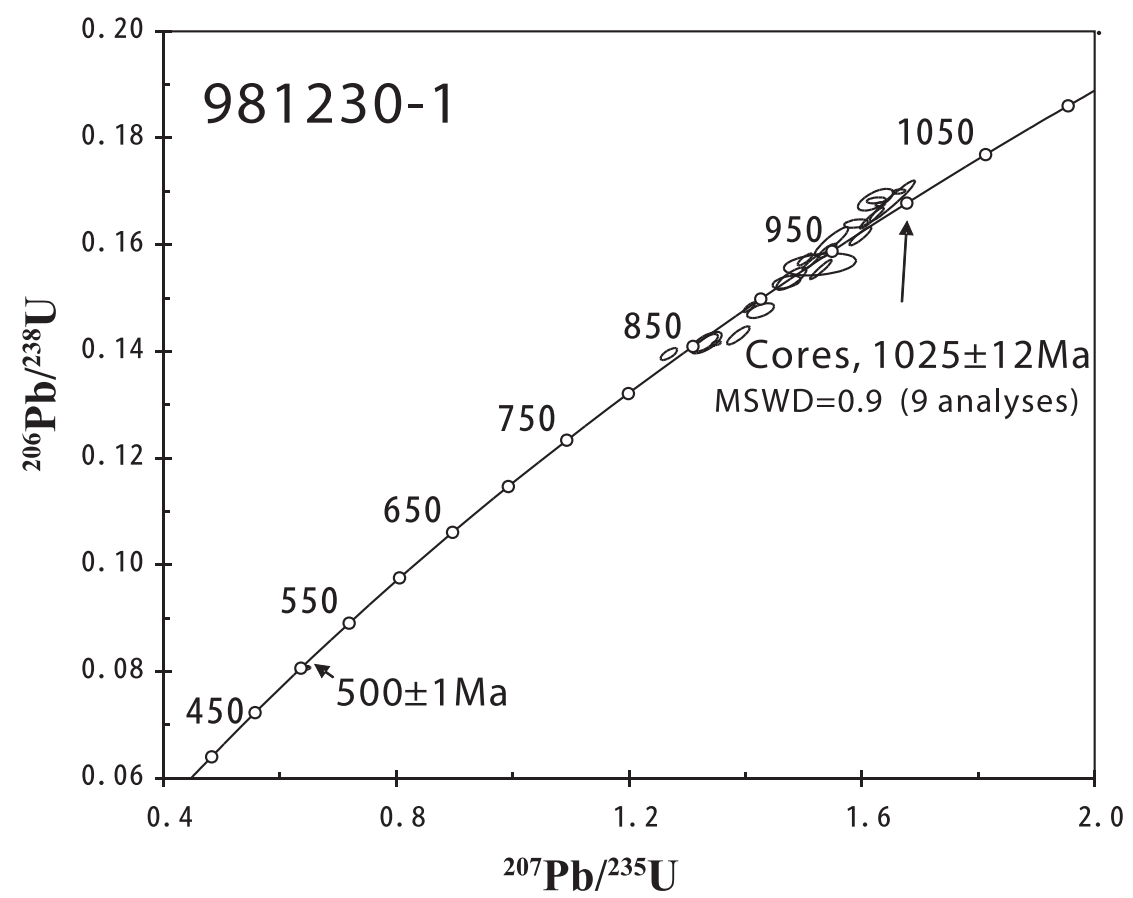

Fig. 15. Concordia diagrams showing SHRIMP data for sample 981230. Error ellipses are $1 \sigma$. 
606 Y. Wang and others_Shrimp zircon age constraints from the Larsemann Hills region,

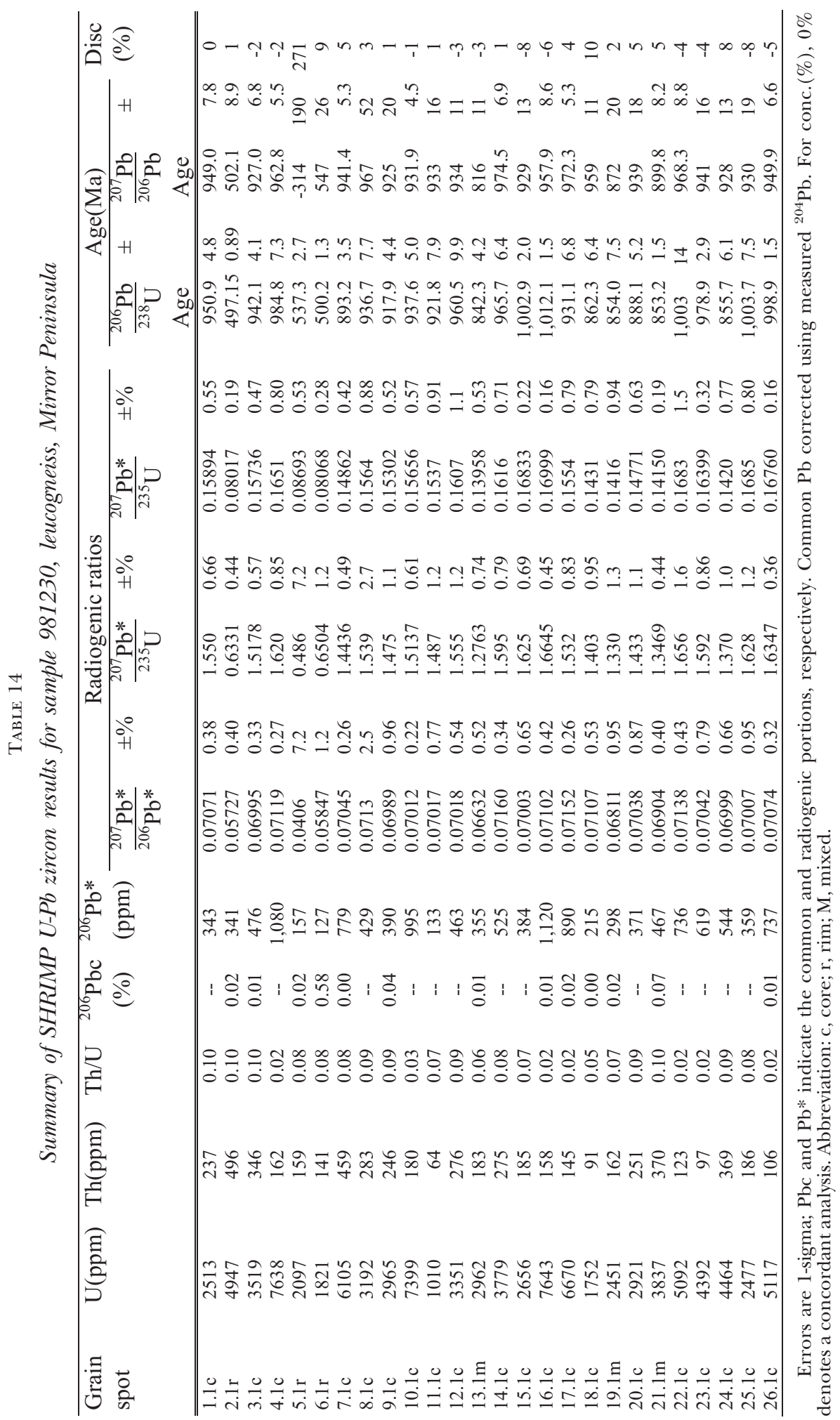


Based on the zircon characteristics, we interpret the leucogneiss as being derived from melting of a metasediment that experienced two zircon overgrowth events.

\section{IMPLICATIONS OF THE ZIRCON DATA}

The intensity of overprinting renders an unambiguous interpretation of late Meso- to early Neoproterozoic metamorphic ages extremely difficult. It is apparent that zircons in the study area reflect a ca. $1.13 \mathrm{Ga}$ felsic intrusive event, a ca. 1.0 Ga metamorphic and igneous emplacement event and a late Pan-African (0.53 Ga) tectono-thermal event.

The complicated patterns of recrystallization, overgrowths and rims revealed by CL imagery demonstrate that the zircons of this study are not amenable to conventional analysis. Studies that have used bulk zircon fractions or fragments (Tong and others, 1995; Zhang and others, 1996) obtained ages that probably reflected mixtures of different components. Combining CL images and SHRIMP analysis allows different parts of grains with different U-contents to be examined; therefore, it was possible to obtain older protolith and thermal event ages. The new ages and information on the complexity of the zircons have implications for the interpretation of previous wholerock isotopic studies. The whole-rock $\mathrm{Rb}-\mathrm{Sr}$ and $\mathrm{Sm}-\mathrm{Nd}$ systems previously studied (Sheraton and others, 1984; Zhao and others, 1995) were most probably disturbed. The zircon data presented here reveal a record of the Precambrian history in the Larsemann Hills and adjacent areas. The SHRIMP data demonstrate evidence for a ca. 1.1 Ga minimum age for a felsic gneiss protolith and major disturbances at ca.1.0 Ga and $0.5 \mathrm{Ga}$.

The paragneiss samples have detrital zircon age spectra in the range 2.2 to $1.1 \mathrm{Ga}$ with a prominent peak at $1.1 \mathrm{Ga}$. Rims give late Mesoproterozoic (ca. 1.0 Ga) and early Paleozoic ages (dominantly $0.53 \mathrm{Ga}$ ), consistent with the age of metamorphism. Although zircon ages can be notoriously difficult to tie to metamorphic P-T paths, the zircon ages from this study are interpreted to record the timing of two phases of high-grade metamorphism. Zircon overgrowth on Mesoproterozoic cores represent metamorphic and/or anatectic modifications of the host rock at ca. 1000 and $530 \mathrm{Ma}$. Cores showing round or embayed shapes indicate resorption via metamorphic mineral reactions or melting. Wide overgrowths of both ages reflect substantial new zircon growth at high temperature. Our data for the $\sim 1000 \mathrm{Ma}$ overgrowths on zircons from paragneisses define a period of late Mesoproterozoic metamorphism in the Larsemann Hills and adjacent areas.

A high-grade event at ca. $1000 \mathrm{Ma}$ is also indicated by SHRIMP U-Pb ages for magmatic zircons in leucogneiss from the Rauer Group (Kinny and others, 1993) and from Sm-Nd garnet ages for a mafic orthogneiss at Søstrene Island, immediately southwest of Bolingen Islands (Hensen and Zhou, 1995). Despite extensive isotopic evidence for high-grade metamorphism in the Rauer Group at 550 to $500 \mathrm{Ma}$, the preservation of monazite $\mathrm{U}-\mathrm{Pb}$ ages near $1000 \mathrm{Ma}$ in metasedimentary rocks on Filla Island, Rauer Group, confirm the importance of the 1030 to 1000 Ma event (Harley, 2003). This means that the ca. 1.0 Ga tectono-thermal event in Prydz Bay, East Antarctica, is now well established.

Peak P-T estimates of $\sim 10 \mathrm{kbar}$ and $900{ }^{\circ} \mathrm{C}$ from a garnet-bearing mafic orthogneiss at Søstrene Island (Thost and others, 1991, 1994; Hensen and Zhou, 1995) indicate high-grade metamorphism in Prydz Bay, and garnet Sm-Nd ages suggest that the high-grade assemblages in the mafic orthogneiss formed during the ca. $1000 \mathrm{Ma}$ event. Two generations of retrograde symplectite occur around garnet in the mafic orthogneiss at Søstrene Island, reflecting re-equlibration at progressively lower pressures (Thost and others, 1991). An early coarse-grained orthopyroxene-plagioclase symplectite probably reflects decompression during the ca. $1000 \mathrm{Ma}$ event $\left(\mathrm{M}_{1}\right)$, at peak conditions of $\sim 10 \mathrm{kbar}$ and 850 to $900{ }^{\circ} \mathrm{C}$, which resulted in the retrograde 
breakdown of garnet according to Grt + Qtz $\rightarrow$ Opx + Plag, but P-T estimates of $6 \mathrm{kbar}$ and $750{ }^{\circ} \mathrm{C}$ for a later, fine-grained orthopyroxene-plagioclase-spinel symplectite are consistent with a ca. $500 \mathrm{Ma}\left(\mathrm{M}_{2}\right)$ overprint on the ca. $1000 \mathrm{Ma}$ orthogneiss assemblage (Hensen and others, 1995). Our isotopic dating yielded an age of ca. $1000 \mathrm{Ma}$, close to the garnet-bearing granulites, and in keeping with a known early Neoproterozoic granulite-facies event at $\geq 988 \mathrm{Ma}$, even though the temperatures required for granulite formation (with strong partial melting) at 550 to 500 Ma should have obliterated any earlier signal. Our data reveal an important tectono-thermal event at ca. $1000 \mathrm{Ma}$ and may constrain the true age of the late Meso- to early Neoproterozoic orogeny as originally conceived by Tingy (1982) and Sheraton and others (1984). We emphasize, however, that this tectono-thermal event is evident only from the SHRIMP zircon ages.

The summary of the interpreted age data (fig. 16) shows a 1.1 Ga felsic-mafic composite gneiss protolith being partially reset by a 1.0 Ga metamorphic event, and minor recent Pb-loss causing some data to fall below concordia. The $0.53 \mathrm{Ga}$ age tectono-thermal event overprint mostly caused $\mathrm{Pb}$ loss on older ca.1.1 Ga and ca. 1.0 Ga zircons. The early Paleozoic orogeny is related to a major collisional event in East Gondwanaland.

The above geochronological data support the notion that the study region experienced a late Meso- to early Neoproterozoic (ca. $1000 \mathrm{Ma}$ ) high-grade tectonothermal event, and an early Paleozoic (ca. $500 \mathrm{Ma}$ ) event.

The metamorphic evolution of the different lithological units as deduced from SHRIMP zircon dating and geological data is summarized in table 15 (Wang and others 2003, 2004).

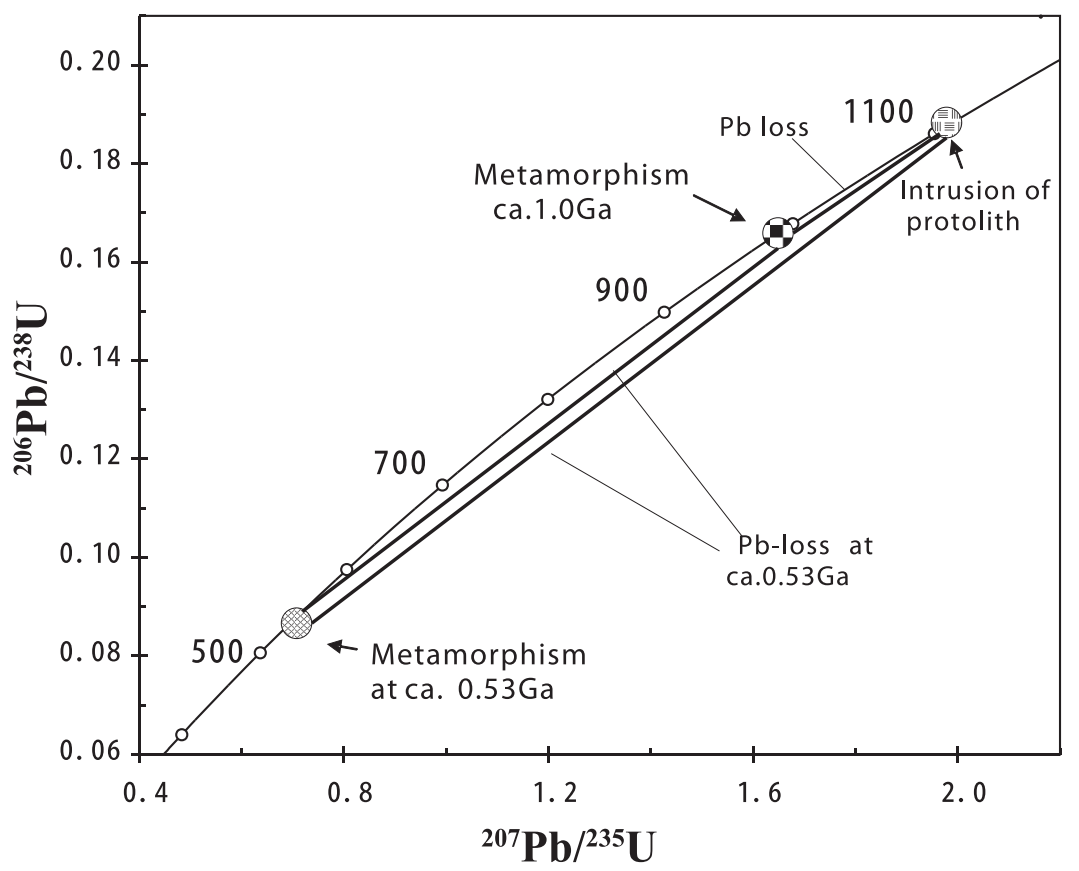
areas.

Fig. 16. Schematic illustration of major events affecting samples from Larsemann Hills and adjacent 
TABLE 15

Summary of the litho-tectonic and metamorphic evolution as determined by U-Pb SHRIMP zircon analyses and $\mathrm{Sm}-\mathrm{Nd}$ data

\begin{tabular}{|c|c|c|}
\hline \multirow{5}{*}{ 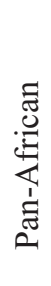 } & Dalkoy granite & $501 \pm 11 \mathrm{Ma}$ \\
\hline & Pegmatite & $504 \pm 17 \mathrm{Ma}$ \\
\hline & Progress granite & $516 \pm 7 \mathrm{Ma}$ \\
\hline & Leucogranite & $524 \pm 20 \mathrm{Ma}$ \\
\hline & $\mathrm{D}_{3}: \mathrm{N}-\mathrm{S}$ extension event & \\
\hline & $\mathrm{D}_{2}$ : WNW-directed thrusting event, $\mathrm{M}_{2}$ : granulite-facies & $529 \pm 8 \mathrm{Ma}$ \\
\hline \multirow{5}{*}{ 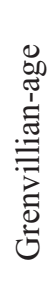 } & Enderbite intrusion & $971 \pm 17 \mathrm{Ma}$ \\
\hline & Granitic gneiss intrusion & ca. $1000 \mathrm{Ma}$ \\
\hline & $\begin{array}{l}D_{1} \text { : interleaving of mafic-felsic gneiss and sedimentary rocks, } M_{1} \text { : } \\
\text { granulite-facies }\end{array}$ & ca.1000 Ma \\
\hline & Metasedimentary rocks (pelite, psammite, quartzite, etc.) & \\
\hline & felsic intrusives & ca.1100 Ma \\
\hline
\end{tabular}

REGIONAL GEOLOGICAL COMPARISONS AND IMPLICATIONS

Several reconstructions have been proposed for the assembly of Rodinia, based on geological, isotopic and paleomagnetic data (see review in Unrug, 1997; Fitzsimons, 2000; Torsvik, 2003). The Prydz Bay ca. 1.0 Ga age mobile belt, as a part of the Circum East Antarctica mobile zone, was assumed to be related to the assembly of Rodinia (Moores, 1991; Dalziel, 1991; Hoffman, 1991; Powell and others, 1993; Torsvik, 2003). However, recent work has cast doubt on the Rodinia paleogeography and on the timing of its assembly and break-up (Fitzsimons, 2000). The recent recognition of intense high-grade metamorphism and deformation at ca. 0.5 Ga in Prydz Bay and Lützow-Holm Bay refutes the notion of a coherent circum-East Antarctic "early Neoproterozoic" orogenic belt (Shiraishi and others, 1992, 1994; Fitzsimons, 2000; Harley, 2005) and suggests that India and Antarctica did not fuse until the early Paleozoic. Thus, the origin of ca. $1 \mathrm{Ga}$ age metamorphism in India and Antarctica needs to be reassessed.

Magmatism and metamorphism at $1000 \mathrm{Ma}$ is well established in the Eastern Ghats belt of India (Paul and others, 1990) and in much of the Antarctic crust adjacent to the Prydz Bay region (Black and others, 1987; Kinny and others, 1993, 1997; Boger and others, 2000; Carson and others, 2000, Wang and others, 2007). SHRIMP zircon ages of various rocks from Larsemann Hills and adjacent areas indicate that metamorphic assemblages are composed of late Mesoproterozoic to early Neoproterozoic rocks that most likely were part of the Eastern Ghats belt-Northern Prince Charles MountainsMawson Coast-Rayner Complex orogenic belts in East Antarctica and India (fig. 17; 


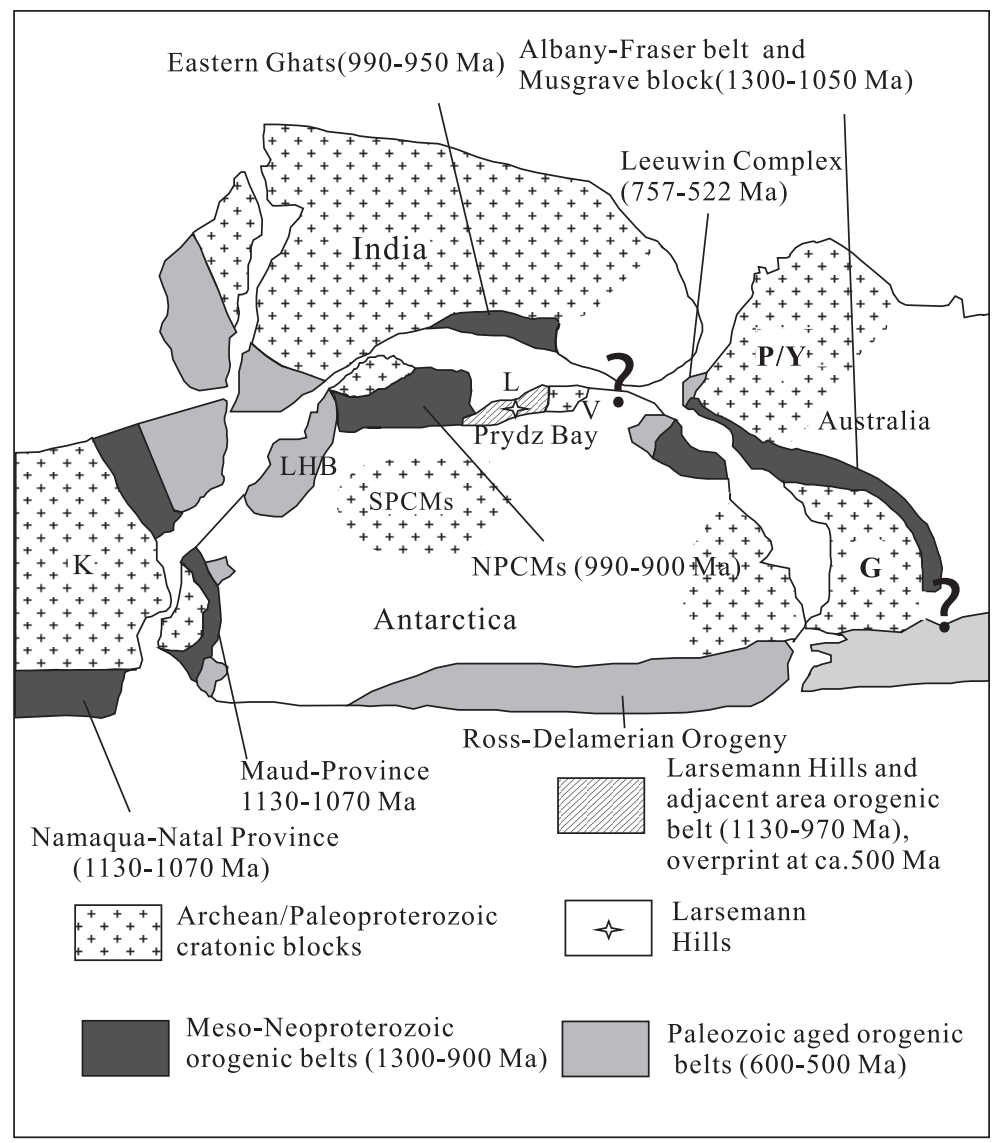

Fig. 17. Tectonic map of East Antarctica and adjacent parts of Gondwana showing ArcheanPaleoproterozoic cratonic blocks, and Meso-Neoproterozoic and Paleozoic orogenic belts (after Boger and others, 2000). The disparate ages of the Meso-Neoproterozoic orogenic belts, which have previously been correlated, and the recently recognized intervening Paleozoic belts in Prydz Bay are illustrated. G, Gawler craton; K, Kalahari craton; sPCMs, southern Prince Charles Mountains; V, Vestford Hills; LHB, Lüzow-Holm Bay; P, Prydz Bay; nPCMs, northern Prince Charles Mountains.

Kinny and others, 1993, 1997; Young, and others, 1997; Boger and others, 2000; Carson and others, 2000, 2007). Northern Prince Charles Mountains-Mawson Coast were deformed and metamorphosed between ca. 990 and $920 \mathrm{Ma}$ and accompanied by widespread emplacement of voluminous granites and charnockites, periods of magmatism and metamorphism that, in part, coincides with that recorded for the orthogneisses in Prydz Bay. It is possible that ca. 1130 to 1100 Ma intrusions from pre-orogenic orthogneiss proliths, similar to those observed in Prydz Bay, are present in the northern Prince Charles Mountains but remain unrecognized (Carson and others, 2007).

Regional zircon geochronology of East Antarctica shows that voluminous magmatism in northern Prince Charles Mountains, the Rauer Group and Larsemann Hills and adjacent areas was broadly synchronous during the late Meso- to early Neoproterozoic period (Kinny and others, 1993, 1997; Carson and others, 2000; Boger and others, 2000). The Rayner experienced key events at 1000 to $980 \mathrm{Ma}$, and $925 \mathrm{Ma}$, with magmatism at ca. 960 Ma. The Rauer Group preserves a magmatic - metamorphic 
record from ca. $1080 \mathrm{Ma}$ to $990 \mathrm{Ma}$, and the Maud Province has $1130 \mathrm{Ma}$ magmatic rocks overprinted at 1030 to $990 \mathrm{Ma}$ (Harley, 2003). Regional metamorphism (ca. 1000 Ma) in the Eastern Ghats belt, northern Prince Charles Mountains, Rauer Group, Mawson Coast, Rayner, Maud Province and Larsemann Hills are broadly synchronous. However, other aspects of their geological records were apparently not synchronous, for example, the ca. 960 Ma Rayner magmatic event and northern Prince Charles Mountains magmatism were prolonged over an extended period from ca. $980 \mathrm{Ma}$ to ca. $910 \mathrm{Ma}$ (Kinny and others, 1997; Boger and others, 2000; Carson and others, 2000). There appear to be some tens to near one hundred million year age differences within the Circum-East Antarctic Orogen. However, it may be pointed out that a large orogen should not necessarily exhibit the same peak orogenic ages throughout (Yoshida, 2007). In fact, almost all early Paleozoic areas of tectono-metamorphic activity (for example, Prydz Bay and Lützow-Holm Bay) carry distinct evidence of late Meso- to early Neoproterozoic components at ca. 1 Ga (Shiraish and others, 1994). Furthermore, these terrains are characterized by superimposed deformations and metamorphisms and by a lack of ophiolites. Such evidence supports the view that the early Paleozoic orogens were intracratonic rather than intercratonic; that is, they were not the result of suturing (Yoshida, 2007).

On the basis of structural and argon thermochronology, Wilson and others (2007) proposed that the ca. 550 to 500 Ma high-grade event in the Rauer Group, Prydz Bay, should be attributed to an intracratonic deformation regime. We suggest that the regional magmatic and metamorphic events were spatially linked within a single block during assembly of the late Mesoproterozoic-early Neoproterozoic Rodinia supercontinent. Evidence for Rodinia assembly is provided by widespread late Mesoproterozoic orogenic belts that record the terminal phases of orogenesis at ca. 1100 to $1000 \mathrm{Ma}$ (Hanson and others, 2004). However, models proposed for the assembly of Prydz Bay and other Mesoproterozoic continental blocks remain the subject of debate. The absence of blueschists, accretionary complexes or mélange zones, belts of magmatic arc-type rocks, and ophiolite complexes in different Mesoproterozoic blocks has been used to support other models. Perhaps the 1100 to 1000 Ma event reflects an arc accretion event rather than the final consolidation of East Gondwana.

Further work is required to reassess current models for the assembly of a Proterozoic supercontinent in the light of new zircon evidence for the late Meso- to early Neoproterozoic and early Paleozoic events within East Gondwana.

\section{CONCLUSIONS}

1. SHRIMP ages show that zircons from gneissic Mesoproterozoic protoliths in the Larsemann Hills experienced metamorphic overgrowths at ca. $1000 \mathrm{Ma}$; a paragneiss contains zircons with metamorphic crystallization ages of ca. $1000 \mathrm{Ma}$; a syntectonic enderbite and granitic gneiss yielded concordant zircon crystallization ages of ca. 1000 Ma. These isotopic ages provide the first direct evidence for the recognition of a late Mesoproterozoic to early Neoproterozoic high-grade event in the Larsemann Hills and is in agreement with a Sm-Nd mineral isochron age for mafic granulites presented by Hensen and others (1995).

2. Our age data provide good time constraints for crystallization ages around 1.1 $\mathrm{Ga}$ for felsic gneisses in the study area. Multiple episodes of zircon growth in these rocks suggests that the Larsemann Hills region was subjected to at least two major tectono-thermal events, one at ca. $1000 \mathrm{Ma}$, the other at ca. $530 \mathrm{Ma}$. There is no conclusive evidence for the mafic-felsic composite orthogneiss to represent an Archean basement complex to the metasedimentary sequence of the Larsemann Hills.

3. Our data confirm the East Gondwana nature of early ca. 1 Ga zircon growth in the Larsemann Hills and adjacent areas, suggesting that this event is widespread in the Prydz Bay region. This provides important constraints on the evolution of the Rodinia 
and Gondwana supercontinents. The Larsemann Hills and adjacent areas are interpreted to have experienced a major metamorphic event at $\sim 1.0 \mathrm{Ga}$, possibly as part of a 1.0 Ga mobile belt (Dalziel, 1991; Hoffman, 1991; Tingey, 1991; Powell and others, 1993; Yoshida, 1995; Yoshida and others, 2003), which is exposed throughout the northern Prince Charles Mountains-Mawson Coast-Rayner Complex and is part of the Eastern Ghats belt, eastern Antarctica and India (fig. 17). The newly defined chronology also fits with the Maud region (magmatism at $1130 \mathrm{Ma}$, metamorphism at 1050-990 Ma). The $\sim 1.0 \mathrm{Ga}$ event was overprinted by an intense early Paleozoic thermal event at ca. $0.53 \mathrm{Ga}$.

4. The depositional age of the paragneiss sequences is Mesoproterozoic at ca. 1.1 Ga. The paragneisses preserve isotopic ages that are consistent with an immature source and are derived from orthogneisses prior to the $1.0 \mathrm{Ga}$ event.

\section{ACKNOWLEDGMENTS}

We thank the Chinese Arctic and Antarctic Administration for logistic support in the 1992-93, 1998-99, and 2001-02 summers and Ian Williams for assistance in preparing the zircon mounts at ANU. This research was supported by the National Natural Science Foundation of China (Grants Nos. 40773042, 40573039, 40272081 and 49702033) and the Basic Outlay of Scientific Research Work (J0704) from the Ministry of Science and Technology of the People's Republic of China. The manuscript was completed when the senior author was visiting NTU. We also thank Alfred Kröner, Mainz, Germany, for suggestions and comments to improve the manuscript. Helpful reviews by Simon L. Harley and Chris Carson are also gratefully acknowledged.

Appendix: Sample Descriptions

On Steinnes Peninsula, Kolloy Island and Vögoy Island, felsic-mafic composite orthogneisses are well exposed (Fitzsimons and Harley, 1991, 1992, 1997; Thost and others, 1992, 1994; Carson and others, 1995). These rocks largely consist of felsic gneiss with discontinuous pods, boudins and layers of mafic units that generally comprise around 10 to 20 percent, but locally up to 50 percent of the total rock volume (Carson and others, 1995). Felsic-mafic composite gneiss samples were selected to determine the age of both emplacement and metamorphism in the study area, and to determine the polyphase metamorphic overprint by dating complex metamorphic zircon overgrowths. On Grovness Peninsula, a massive but well-foliated non-megacrystic orthopyroxene- tonalite body is exposed in the southern part; an intrusive origin is preferred, based on the massive, homogenous nature of this unit (Carson and others, 1995). On Stornes Peninsula and south of Nella Lake, a granitic intrusive contact is exposed between a granitic gneiss and a paragneiss sequence. At this locality both enderbite and granitic gneiss samples were collected to determine the age of emplacement and late metamorphism.

Samples of paragneiss were collected from Broknes Peninsula and on Vögoy Island to determine the detrital zircon signature and the age of metamorphism associated with tectono-thermal events. On Mirror Peninsula, a leucogneiss was collected to obtain an estimate for the timing of metamorphism and partial melting.

\section{FELSIC GNEISS}

Composite orthogneiss is exposed on Steinnes Peninsula and on the northern offshore islands. The orthogneiss comprises interleaved mafic and felsic material in variable proportions, and felsic orthogneiss is typically more abundant (Fitzsimons and Harley, 1991, 1992; Thost and others, 1992, 1994; Carson and others, 1995). The gneiss is inferred to represent a "basement" to the metasedimentary sequences of the Larsemann Hills. Felsic rocks typically comprise quartz, plagioclase, orthopyroxene, and biotite, whereas mafic compositions comprise hornblende, orthopyroxene, clinopyroxene and plagioclase \pm quartz with variable amounts of garnet. Several workers have also suggested a tentative correlation between the orthogneiss, the Archean orthogneiss complex of the Vestfold Hills and tectonically reworked Archean orthogneiss in the Rauer Group. However, isotopic evidence suggests that these crustal fragments are temporally unrelated.

Three representative felsic gneiss samples were selected for SHRIMP analysis, two samples (9926-5; 9921-14) from Steinnes Peninsula and a neighboring non-named small island, one (K217-3) from Kölloy Island, The felsic gneiss largely comprises orthopyroxene, quartz, plagioclase, ilmenite and biotite and 
locally garnet. The felsic mineralogies are dominated by plagioclase with little or no K-feldspar and suggest tonalitic to granodioritic protoliths (Sheraton and Collerson, 1983).

Sample 9926-5 was collected on Penguin Island, to the north of Steinnes Peninsula, The small outcrop has not been described before in a formal report. A thick unit of felsic-mafic gneisses is exposed from which felsic gneiss sample 9926-5 was taken. The gneiss mineralogy is dominated by plagioclase and orthopyroxene, with biotite and ilmenite as minor components, and zircon and apatite as accessories, suggesting a tonalitic protolith.

Sample 9921-14 was collected on the northern side of Steinnes Peninsula where a strongly deformed sequence of felsic gneisses is interlayered with rafts and schlieren of dark, mafic granulite. The felsic gneiss sample consists of the assemblage quartz-plagioclase-K-feldspar- orthopyroxene-biotite-ilmenite.

Sample K217-3 was collected in the north of Kolloy Island and is an orthopyroxene-bearing felsic gneiss previously interpreted to represent a basement complex (Carson and others, 1995).

2. MAFIC GNEISS

Mafic gneisses occur as dismembered oriented distributed lenses, pods, layers and occur in felsic gneiss and metapelite in the Larsemann Hills and adjacent areas. Their intrusive origin is apparent from their abundance within the felsic gneiss, in which they occur as boudinaged and isoclinally folded layers. Within the paragneiss, mafic boudins commonly display contacts parallel to the compositional layering (Dirks and others, 1993). For example, in Steinnes Peninsula outcrops, the mafic gneisses occur as parallel, long, narrow $\left(1 \times 15 \mathrm{~m}^{2}\right)$ lenses within felsic gneiss, suggesting that they were originally mafic dikes (Dirks and others, 1993; Wang and others, 1994). This indicates that the mafic granulite protoliths were emplaced in an extensional environment. A combined cathodoluminescence (CL) and SHRIMP single zircon study revealed relict igneous zoning and metamorphic overgrowths. Four samples (93122-15, 98129-1, K217-4, V218-5) were selected for ion microprobe analysis.

Sample 93122-15 appears as a lens within the basement composite orthogneiss on Fold Island and is a mafic granulite composed of orthopyroxene + clinopyroxene + plagioclase \pm biotite.

Sample F129-1, from Steinnes Peninsula, is a raft of dark mafic granulite, enclosed within pale brown felsic orthogneiss. It is dominated by hornblende, plagioclase orthopyroxene, clinopyroxene, and ilmenite.

Sample K217-4, from northern Kolloy Island, is a mafic gneiss occurring as a layer within the felsic gneiss. It was interpreted as a basement orthogneiss (Fitzsimons and Harley, 1991; Carson and others, 1995; Fitzsimons, 1997). The sample is composed of orthopyroxene, hornblende, and plagioclase, biotite, minor magnetite and quartz, with zircon as accessory mineral.

Sample V218-5 was collected from a mafic granulite in the west of Vögoy Island, North Bolingen Islands, northwest of Larsemann Hills (GPS: $69^{\circ} 26^{\prime} 300$ S, $75^{\circ} 43^{\prime} 854 \mathrm{E}$ ). It consists of biotite gneiss with abundant remnants of an orthopyroxene-hornblende-plagioclase-bearing precursor (Dirks and Hand, 1995). The mafic gneiss was intruded by pegmatite veins up to $5 \mathrm{~m}$ in width and occurs as blocks and discontinuous layers (ca. $200 \times 250 \mathrm{~m}$ ). The primary nature of the orthogneiss-paragneiss contact is difficult to determine due to subsequent deformation and transposition. The origin of the protolith is not clear. Rocks on Vögoy Island are nearly identical to those in the Larsemann Hills immediately to the northeast (Sheraton and others, 1984; Stüwe and others, 1989; Dirks and others, 1993). The $\mathrm{D}_{3}$ domain on Vögoy Island can be traced into the southwest Larsemann Hills. The sample has a mafic composition, containing orthopyroxene, hornblende, plagioclase, biotite \pm quartz;

3. PARAGNEISS

The paragneiss sequence comprises a range of lithologies, including metapelite, semi-pelite, psammite and metaquarzite, with minor metabasite and calc-silicate (Stüwe and others, 1989; Dirks and others, 1993; Thost and others, 1994; Carson and others, 1995; Dirks and Hand, 1995; Fitzsimons, 1997). The depositional age of the paragneiss sequences is controversial in the Larsemann Hills and adjacent areas. Fitzsimons (1997) reported that the paragneiss preserves no conclusive evidence of earlier metamorphism. To obtain accurate information on the timing of metamorphism, zircons were separated from metasedimentary rocks at Seal Cove, south of Nella Lake and Vogoy Island.

Sample 981227-1 was collected at Seal Cove, Mirror Peninsula. The metapelite contains quartz, biotite, cordierite, alkali feldspar, sillimanite, garnet, plagioclase, spinel, magmatite, zircon, monazite and apatite.

Sample S226-4 is a Sill-Cord-Magnetite-Pl-Qtz-gneiss and was collected from the west of Seal Cove. It is one of the major lithological associations.

Sample V218-4 is a Grt-Sil-Bt-Pl-Qtz-Mt-gneiss from Vögoy Island, North Bolingen Islands, northwest of the Larsemann Hills. 


\section{$614 Y$. Wang and others-Shrimp zircon age constraints from the Larsemann Hills region,}

$$
\text { 4. ENDERBITE }
$$

Enderbite is exposed as massive bodies in Grovness. It is dominated by plagioclase and quartz with orthopyroxene. Small amounts of magnetite, monazite, zircon and apatite are accessory phases. Primary contact relations amongst enderbite and granitic gneiss are obscured by strong ductile deformation, but an intrusive origin is preferred (Carson and others, 1995). Sample 981221-2 was collected from Grovness.

$$
\text { 5. GRANITIC GNEISS }
$$

On the northwest shore of Mirror Peninsula, west of Broknes Peninsula, Stornes Peninsula and Storneskola, some large body granitic orthogneiss are exposed (fig. 2) which contain mafic pods and lenses and are strongly deformed. The mafic pods and lenses carry relicts of a hornblende-plagioclase- orthopyroxene-biotite-clinopyroxene \pm garnet assemblage that indicates medium pressure at granulite-facies metamorphic conditions (Wang and others, 1994). Intrusive relationships are rarely seen; these granitic gneisses contain gneissic layering concordant with the foliation in the surrounding sill-bearing gneiss, where intrusive boundaries are transposed within the gneissic layering. It generally forms a homogeneous unit with equigranular granitic appearance (Carson and others, 1995). Two samples were analyzed, S204-1 and F127-4 (fig. 2).

Sample F127-4 was collected on the south side of Lake Nella (fig. 2) and is a medium-grained granitic gneiss that occurs within Grt-Sill-Sp-Pl-Qtz \pm Bt gneiss with sharp lithological boundaries. The sample consists of plagioclase, quartz, K-feldspar, and variable amounts of garnet and biotite.

Sample S204-1 was collected from the north of Stornes Peninsula and is composed of quartz, plagioclase, K-feldspar and variable amounts of garnet and biotite. Accessory minerals are apatite, ilmenite, monazite and zircon.

\section{LEUCOGNEISS}

Grt-bearing leucogneiss sample 981230 was collected on eastern Mirror Peninsula (fig. 2). The rock was described by Carson and others (1995) from the same location and named as Zhongshan gneiss. It preserves a foliation defined by stringers of garnet, rare biotite and a compositional banding defined by quartzfeldspar leucosomes (Carson and others, 1995). The leucogneiss is concordant with the surrounding Grt-Sill-Cord-Bt-Pl-Qtz gneiss (Stüwe and others, 1989).

\section{REFERENCES}

Black, L. P., Harley, S. L., Sun, S. S., and McCulloch, M. T., 1987, The Rayners Complex of east Antarctica, complex isotopic systematic within a Proterozoic mobile belt: Journal of Metamorphic Geology, v. 5 , p. 1-26.

Black, L. P., Kamo, S. L., Allen, C. M., Aleinikoff, J. N., Davis, D. W., Korsch, R. J., and Foudoulis, C., 2003, TEMORA 1: a new zircon standard for Phanerozoic U-Pb geochronology: Chemical Geology, v. 200, p. 155-170.

Boger, S. D., Carson, C. J., Wilson, C. J. L., and Manning, C. M., 2000, Neoproterozoic deformation in the northern Prince Charles Mountains, east Antarctica; evidence for a single protracted orogenic event: Precambrican Research, v. 104, p. 1-24.

Carson, C. J., Dirks, P. H. G. M., Hand, M., Sims, J. P., and Wilson, C. J. L., 1995, Compressional and extensional tectonics in low-medium pressure granulites from the Larsemann Hills, East Antarctica: Geological Magazine, v. 132, p. 151-170.

Carson, C. J., Fanning, C. M., and Wilson, C. J. L., 1996, Timing of the Progress Granite, Larsemann Hills: additional evidence for Early Paleozoic Orogenesis within the east Antarctic shield and implications for Gondwana assembly: Australian Journal of Earth Sciences, v. 43, p. 539-553.

Carson, C. J., Powell, R., Wilson, C. J. L., and Dirks, P. H. G. M., 1997, Partial melting during tectonic exhumation of a granulite terrane: an example from the Larsemann Hills, East Antarctica: Journal of Metamorphic Geology, v. 15, p. 105-126.

Carson, C. J., Boger, S. D., Fanning, C. M., Wilson, C. J. L., and Thost, D., 2000, SHRIMP U-Pb geochronology from Mt Kirkby, northern Prince Charles Mountains, East Antarctica: Antarctic Science, v. 12 , p. $429-442$.

Carson, C. J., Grew, E. S., Boger, S. D., Fanning, C. M., and Christy, A. G., 2007, Age of boron- and phosphorus rich paragneiss and associated orthogneiss in the Larsemann Hills: New constraints from SHRIMP U-Pb zircon geochronology, in Cooper, A. K., Raymond, C. R., and the 10th ISAES Editorial Team, editors, Antarctica: A Keystone in a Changing World - Online Proceedings of the 10th International Symposium on Antarctic Earth Sciences: USGS Open-File Report 2007-1047, Extended Abstract 003, 4 p.

Dalziel, I. W. D., 1991, Pacific margins of Laurentia and East Antarctica-Australia as a conjugate rift pair: evidence and implications for an Eocambrian supercontinent: Geology, v. 19, p. 598-601.

Dirks, P. H. G. M., and Hand, M., 1995, Clarifying temperature-pressure paths via structures in granulite from the Bolingen Islands, Antarctica: Australian Journal of Earth Sciences, v. 42, p. 157-172. 
Dirks, P. H. G. M., Carson, C. J., and Wilson, C. J. L., 1993, The deformation history of the Larsemann Hills, Prydz Bay: The importance of the Pan-African (500Ma) in East Antarctica: Antarctica Science, v. 5 , p. 179-193.

Fitzsimons I. C. W., 1996, Metapelitic migmatites from Brattstrand Bluffs, east Antarctica-metamorphism, melting and exhumation of the mid-crust: Journal of Petrology, v. 37, p. 395-414.

- 1997, The Brattstrand paragneiss and the Søstrene orthogneiss: A review of Pan-African metamorphism and Grenvillian relics in southern Prydz Bay, in Ricci, C. A., editor, The Antarctic Region: Geological Evolution and Processes: Sienna, Terra Antarctica Publication, p. 121-130.

— 2000a, Grenville-age basement provinces in East Antarctica: Evidence for three separate collisional orogens: Geology, v. 28, p. 879-882.

2000b, A review of tectonic events in the East Antarctica Shield and their implications for Gondwana and earlier supercontinents: Journal of African Earth Sciences, v. 32, p. 3-23.

Fitzsimons, I. C. W., and Harley, S. L., 1991, Geological relationships in high-grade gneiss of the Brattstrand Bluffs coastline, Prydz Bay, east Antarctica: Australian Journal of Earth Sciences, v. 38, p. 497-519.

— 1992, Mineral reaction texture in high-grade gneisses: evidence for contrasting pressure-temperature paths in the Proterozoic Complex of East Antarctica, in Yoshida, Y., Kaminuma K., and Shiraishi K. editors, Recent Progress in Antarctic Earth Science: Tokyo, Terra Scientic Publishing, p. 103-111.

Fitzsimons, I. C. W., Kinny, P. D., and Harley, S, L., 1997, Two stages of Zircon and monazite growth in anatectic leucogneiss: SHRIMP constraints on the duration and intensity of Pan-African metamorphism in the Prydz Bay, East Antarctica: Terra Nova. v. 9, p. 47-51.

Gilotti, J. A., and Elvevold, S., 2002, Extensional exhumation of a high-pressure granulite terrane in Payer Land, Greenland Caledonides: Structural, petrologic, and geochronologic evidence from metapelites: Canadian Journal of Earth Sciences, v. 39, p. 1169-1187.

Hanson, R. E., Crowley, J. L., Bowring, S. A., Ramezani, J., Gose, W. A., Dalziel, I. W. D., Pancake, J. A., Sedel, E. K., Blenkinsop, T. G., and Mukwakwami, J. M., 2004, Coeval large-scale magmatism in the Kalahari and Laurentian cratons during Rodinia assembly: Science, v. 304, p. 1126-1129.

Harley, S. L., 2003, Archaean-cambrian crustal development of East Antarctica: metamorphic characteristics and tectonic implications, in Yoshida, M., Windley, B. F., and Dasgupta, S., editors., Proterozoic East Gondwana: Supercontinent Assembly and Breakup: Geological Society Special Publication, v. 206 , p. 203-230.

2005, The geology of Antarctica, in Geology, from Encyclopedia of life support system (EOLSS), Developed under the Auspices of the UNESCO: Oxford, United Kingdom, EOLSS Publishers, http:// www.eolss.net.

Harley, S. L., and Fitzsimons, I. C. W., 1995, High-grade metamorphism and deformation in the Prydz Bay Region, East Antarctica: terranes, events and relational correlations. India and Antarctica during the Precambrian: Geological Society of India Memoir, v. 34, p. 73-100.

Hensen, B. J., and Zhou, B., 1995a, A Pan African granulite facies metamorphic episode in Prydz Bay, Antarctica: evidence from Sm-Nd garnet dating: Australian Journal of Earth Sciences, v. 42, p. 249-258. 1995b, Retention of isotopic memory in garnets partially broken down during an overprinting granulite facies metamorphism: implications for Sm-Nd closure temperature: Geology, v. 23, p. 225228.

1997a, Recognition of multiple high-grade metamorphic events with garnet Sm-Nd chronology in the northern Prince Charles Mountains, Antarctica, in Ricci, C. A., editor, the Antarctic Region, Geological Evolution and Processes: Sienna, Terra Antarctica Publication, p. 97-104.

_ 1997b, East Gondwana amalgamation by Pan-African collision? Evidence in the Prydz Bay region, east Antarctica, in Ricci, C. A., editor, the Antarctic Region, Geological Evolution and Processes: Sienna, Terra Antarctica Publication, p. 115-119.

Hoffman, P. F., 1991, Did the breakout of Laurentia turn Gondwanaland inside out?: Science. v. 252, p. 1409-1412.

Hoskin, P. W. O., and Black, L. P., 2000, Metamorphic zircon formation by solid-state recrystallization of protolith igneous zircon: Journal of Metamorphic Geology, v. 18, p. 423-439.

Ireland, T. R., and Gibson, G. M., 1998, SHRIMP monazite and zircon geochronology of high-grade metamorphism in New Zealand: Journal of Metamorphic Geology, v. 16, p. 149-167.

Kinny, P. D., Black, L. P., and Sheraton, J. W., 1993, Zircon ages and the distribution of Archean and Proterozoic rocks in the Rauer Islands: Antarctic Science, v. 5, p. 193-206.

- 1997, Zircon U-Pb ages and geochemistry of igneous and metamorphic rocks in the northern Prince Charles Mountains, Antarctica: AGSO Journal of Australian Geology and Geophysics, v. 16, p. 637-654

Ludwig, K. R., 2001, Squid 1.02: A user's manual: Berkeley Geochronology Center Special Publication No. 2, $19 \mathrm{p}$.

Meert, J. G., and Torsvik, T. H., 2003, The making and unmaking of a supercontinent: Rodinia revisited: Tectonophysics, v. 375, p. 261-288.

Moores, E. M., 1991, Southwest U.S.-East Antarctic (SWEAT) connection: a hypothesis: Geology. v. 19, p. $425-428$.

Nichols, G. T., and Fahey, A., 1996, Preliminary monazite ages of second generation mylonites, Prince Charles Mountains: Canberra, Abstract, $13^{\text {th }}$ Australian Geological Convention, p. 316-316.

Paul, D. K., Barman, T. R., McNaughton, N. J., Fletcher, I. R., Potts, P. J., Ramakrishnan, M., and Augustine, P. F., 1990, Archean-Proterozoic evolution of Indian Charnockites: Isotopic and Geochemical Evidence from Granulites of the Eastern Ghats Belt: Journal of Geology, v. 98, p. 253-263.

Powell, C. McA., Li, Z. X., McElhinny, M. W., Meert, J. G., and Park, J. K., 1993, Paleomagnetic constraints on timing of the Neoproterozoic breakup of Rodinia and the Cambrian formation of Gondwana: Geology, v. 21, p. 889-892. 


\section{$616 Y$. Wang and others-Shrimp zircon age constraints from the Larsemann Hills region,}

Ren, L., Zhao, Y., Liu, X., and Chen, T., 1992, Re-examination of the metamorphic evolution of the Larsemann Hills, East Antarctica, in Yoshida, Y., Kaminuma, K., and Shiraishi, K., editors, Recent Progress in Antarctic Earth Science: Tokyo, Terra Scientific Publishing Company, p. 145-153.

Rubatto, D., and Gebauer, D., 2000, Use of cathodoluminescence for U-Pb zircon dating by ion microprobe: some examples from the Western Alps, in Pagel, M., Barbin, V., Blanc, P., and Ohnenstetter, D., editors, Cathodoluminescence in geosciences, Volume: Berlin, Heidelberg, New York, Springer, p. 373-400.

Sheraton, J. W., Black, L. P., and McCulloch, M. T., 1984, Regional geochemical and isotopic characteristic of high-grade metamorphics of the Prydz Bay area: the extent of Proterozoic reworking of Archean continental crust in East Antarctica: Precambrian Research, v. 26, p. 169-198.

Shiraishi, K., Hiroi, Y., Ellis, D. J., Fanning, C. M., Motoyoshi, Y., and Nakai, Y., 1992, The first report of Cambrian orogenic belt in East Antarctica-an ion microprobe study of the Lutzow-Holm complex, in Yoshida, Y., Kaminuma, K., and Shiraishi, K., editors, Recent Progress in Antarctic Earth Science: Tokyo, Terra Scientific Publishing, p. 67-73.

Shiraish, K., Ellis, D. J., Hirio, Y., Fanning, C. M., Motoyoshi, Y., and Nakai, Y., 1994, Cambrian orogenic belt in East Antarctica and Sri Lanka: implications for Gondwana assembly: Journal of Geology, v. 102, p. $47-65$.

Stacey, J. S., and Kramers, J. D., 1975, Approximation of terrestrial lead isotope evolution by a two-stage model: Earth and Planetary Science Letters, v. 26, p. 207-221.

Stüwe, K., and Powell, R., 1989, Low-pressure granulite facies metamorphism in the Larsemann Hills area, East Antarctica; Petrology and tectonic implications for the evolution of the Prydz Bay area: Journal of Metamorphic Geology, v. 7, p. 465-483.

Stüwe, K., Braun, H-M., and Peer, H., 1989, Geology and Structure of the Larsemann Hills area, Prydz Bay, East Antarctica: Australian Journal of Earth Sciences,v. 36, p. 219-241, doi: 10.1080/08120098908729483.

Thost, D. E., Hensen, B. J., and Motoyoshi, Y., 1991, Two-stage decompression in garnet-bearing mafic granulites from Søstrene Island, Prydz Bay, East Antarctica: Journal of Metamorphic Geology, v. 9, p. 245-256.

Thost, D. E., Motoyoshi, B. J., and Hensen, B. J., 1992, Mode of occurrence, geochemistry and mineral textures of mafic to ultramafic rocks from the Bolingen Islands, Prydz Bay, East Antarctica, in Yoshida, Y., Kaminuma, K., and Shiraishi, K., editors, Recent Progress in Antarctic Earth Science: Tokyo, Terra Scientific Publishing, p. 113-118.

Thost, D. E., Hensen, B. J., and Motoyoshi, B. J., 1994, The geology of a rapidly uplifted medium to low pressure terrane of Pan-African age: the Bolingen Islands, Prydz Bay, eastern Antarctica: Petrology, v. 2, p. 293-316.

Tingey, R. J., 1981, Geological investigations in Antarctica 1968-1969: The Prydz-Bay-Amery Ice Shelf-Prince Charles Mountains area: Bureau of Mineral Resources Australian Record, 1981, 34.

1982, The geologic evolution of the Prince Charles Mountains-an Antarctic Archaean cratonic block, in Craddock, C., editor, Antarctic Geosciences: Madison, Wisconsin, University of Wisconsin Press, p. $445-464$.

1991, The regional geology of Archaean and Proterozoic rocks in Antarctica, in Tingey, R. J., editor, The Geology of Antarctica: Oxford, Oxford University Press, p. 1-73.

Tong, L., and Liu, X., 1997, The prograde metamorphism of the Larsemann Hills: evidence for an anticlockwise P-T path, in Ricci, C. A., editor, The Antarctic Region: Geological Evolution and Processes: Siena, Terra Antarctica Publication, p. 105-114.

Tong, L., Liu, X., Zhang, L., and Chen, H., 1995, The U-Pb zircon chronology of mafic granulite from the Larsemann Hills, East Antarctica and its possible geological implications: Terra Antarctic, v. 2, p. 123126.

Tong, L., Liu, X., Zhang, L., Chen, H., Chen, F., Wang, Y., and Ren, L., 1998, The ${ }^{40}$ Ar- ${ }^{39}$ Ar ages of hornblendes in Grt-Pl-bearing amphibolite from the Larsemann Hills, East Antarctica and their geological implications: Chinese Journal of Polar Research, v. 9, p. 79-91.

Tong, L., Wilson, C. J. L., and Liu, X., 2002, A high-grade event of $\sim 1100 \mathrm{Ma}$ preserved within the $\sim 500 \mathrm{Ma}$ mobile belt of the Larsemann Hills, east Antarctica: Further evidence from ${ }^{40} \mathrm{Ar}-{ }^{39} \mathrm{Ar}$ dating: Terra Antarctica, v. 9, p. 73-86.

Torsvik, T. H., 2003, The Rodinia jigsaw puzzle: Science, v. 300, p. 1379-1381.

Unrug, R., 1997, Rodinia to Gondwana: The Geodynamic Map of Gondwana Supercontinent Assembly: GSA Today, v. 7, p. 1-6.

Wang, Y., Zhao, Y., Ren, L., Chen, T., Liu, X., and Tong, L., 1994, Geochemical characteristics and medium pressure granulite facies metamorphism of mafic granulite rocks from the Larsemann Hills, East Antarctica: Antarctica Research, v. 6, p. 1-11 (in Chinese with English Abstract).

Wang, Y., Liu, D., Ren, L., and Tang, S., 2003, Advances in SHRIMP geochronology and their constrains on understanding the tectonic evolution of Larsemann Hills, East Antarctica: Terra Nostra, p. 334-335.

Wang, Y., Liu, D., and Tang, S., 2004, Isotopic geochemistry and SHRIMP U-Pb geochronology of mafic-felsic granulites from Larsemann Hills, East Antarctica: Geochimica et Cosmochimica Acta, v. 68, p. 663.

Wang, Y., Tong, L., and Liu, D., 2007, Zircon U-Pb ages from an ultra-high temperature metapelite, Rauer Group, east Antarctica: Implications for overprints by Grenvillian and Pan-African events, in Cooper, A. K., Raymond, C. R., and the 10th ISAES Editorial Team, editors, Antarctica: A Keystone in a Changing World -Online Proceedings of the 10th ISAES: USGS Open-File Report 2007-1047, Short Research Paper 023, 4 p.; doi:10.3133/of2007-1047.srp023.

Williams, I. S., 1998, U-Th-Pb Geochronology by Ion Microprobe, in McKibben, M. A., Shanks III, W. C., and Ridley, W. I., editors, Applications of microanalytical techniques to understanding mineralizing processes: Reviews in Economic Geology, v. 7, p. 1-35. 
Williams, I. S., Compston, W., Black, L. P., Ireland, T. R., and Forster, J. J., 1984, Unsupported radiogenic Pb in zircon: a cause of anomalously high $\mathrm{Pb}-\mathrm{Pb}, \mathrm{U}-\mathrm{Pb}$ and $\mathrm{Th}-\mathrm{Pb}$ ages: Contributions to Mineralogy and Petrology, v. 88, p. 322-327.

Williams, I. S., Buick, I. S., and Cartwright I., 1996, An extended episode of early Mesoproterozoic metamorphic fluid flow in the Reynolds Range, central Australia: Journal of Metamorphic Geology, v. 14 , p. $29-47$.

Wilson, C. J. L., Quinn, C., Tong, L. X., and Phillip, D., 2007, Early Paleozoic intracratonic shears and post-tectonic cooling in the Rauer Group, Prydz bay, East Antarctica constrained by ${ }^{40} \mathrm{Ar} /{ }^{39} \mathrm{Ar}$ thermochronology: Antarctic Science, v. 19, p. 339-353.

Yoshida, M., 1995, Assembly of east Gondwana during the Mesoproterozoic and its rejuvenation during the Pan-African period, in Yoshida, M., and Santosh, M. editors, India and Antarctica during the Precambrian: Geological Society of India Memoir, v. 34, p. 22-45.

2007, Geochronological data evaluation: Implications for the Proterozoic tectonics of East Gondwana: Gondwana Research, v. 12, p. 228-241.

Yoshida, M., Jacobs, J., Santosh, M., and Rajesh, H. M., 2003, Role of Pan-African events in the Circum-East Antarctic orogen of East Gondwana: a critical overview, in Yoshida, M., Windley, B. F., and Dasgupta, S., editors, Proterozoic East Gondwana: Supercontinent Assembly and Breakup: Geological Society Specia Publication, v. 206, p. 57-75.

Young, D. N., Zhao, J., Ellis, D. J., and McCulloch, M. Y., 1997, Geochemical and Sr-Nd isotope mapping of source provinces for the Mawson charnockites, east Antarctica: implications for Proterozoic tectonics and Gondwana reconstruction: Precambrian Research, v. 86, p. 1-19.

Zhang, L., Tong, L., Liu, X., and Scharer, U., 1996, Conventional U-Pb age of the high-grade metamorphic rocks in the Larsemann Hills, East Antarctica, in Pang, Z. H., editor, Advances in Solid Earth Sciences: Beijing, Science Press, p. 27-35.

Zhao, Y., Song, B., Wang, Y., Ren, L., Li, J., and Chen, T., 1992, Geochronology of the late granite in the Larsemann Hills, East Antarctica, in Yoshida, Y., Kaminuma, K., and Shiraishi, K., editors, Recent Progress in Antarctic Earth Science: Tokyo, Terra Scientific Publishing, p. 153-169.

Zhao, Y., Liu, X., Song, B., Zhan, Z., Li, J., Yao, Y., and Wang, Y., 1995, Constraints on stratigraphic age of metasedimentary rocks of the Larsemann Hills, East Antarctica: possible implication for Neoproterozoic tectonics: Precambrian Research, v. 75, p. 175-188.

Zhao, Y., Liu, X., Wang, S., and Song, B., 1997, Syn-and Post-tectonic cooling and exhumation in the Larsemann Hills, East Antarctica: Episodes, v. 20, p. 122-127.

Zhao, Y., Liu, X. H., Liu, X. C., and Song, B., 2003, Pan-African events in Prydz Bay, East Antarctica, and their implications for East Gondwana tectonics, in Yoshida, M., Windley, B. F., and Dasgupta, S., editors. Proterozoic East Gondwana: Supercontinent Assembly and Breakup: London, Geological Society Special Publication, v. 206, p. 231-245. 